\title{
Understanding of Traditional Knowledge and Indigenous Institutions on Sustainable Land Management in Kilimanjaro Region,
} Tanzania

\author{
Richard Y. M. Kangalawe ${ }^{1}$, Christine Noe ${ }^{2}$, Felician S. K. Tungaraza ${ }^{3}$, Godwin Naimani ${ }^{4}$, \\ Martin Mlele 5 \\ ${ }^{1}$ Institute of Resource Assessment, University of Dar es Salaam, Dar es Salaam, Tanzania \\ ${ }^{2}$ Department of Geography, University of Dar es Salaam, Dar es Salaam, Tanzania \\ ${ }^{3}$ Department of Sociology and Anthropology, University of Dar es Salaam, Dar es Salaam, Tanzania \\ ${ }^{4}$ Department of Statistics, University of Dar es Salaam, Dar es salaam, Tanzania \\ ${ }^{5}$ Alpha and Omega Consulting Group Limited, Dar es Salaam, Tanzania \\ Email:acocg@yahoo.com
}

Received 22 October 2014; revised 28 November 2014; accepted 7 December 2014

Copyright (C) 2014 by authors and Scientific Research Publishing Inc.

This work is licensed under the Creative Commons Attribution International License (CC BY).

http://creativecommons.org/licenses/by/4.0/

(c) (7) Open Access

\section{Abstract}

The paper is based on a study whose objective is to provide an understanding of the extent to which traditional knowledge and indigenous institutions for natural resource governance remain relevant to solving current land degradation issues and how they are integrated in formal policy process in Kilimanjaro Region. Data collection for this study combined qualitative and quantitative methods. A total of $\mathbf{2 2 1}$ individuals from households were interviewed using a structured questionnaire; 41 in-depth interviews and 24 focus group discussions were held. Findings indicate that the community acknowledges that there is traditional knowledge and indigenous institutions regarding sustainable land management. However, awareness of the traditional knowledge and practices varied between districts. Rural-based districts were found to be more aware and therefore practiced more of traditional knowledge than urban based districts. Variations in landscape features such as proneness to drought, landslides and soil erosion have also attracted variable responses among the communities regarding traditional knowledge and indigenous practices of sustainable land management. In addition, men were found to have more keen interest in conserving the land than women as well as involvement in other traditional practices of sustainable land management. This is due to the fact that, customarily, it is men who inherit and own land. This, among other factors, could have limited the integration of traditional knowledge and indigenous institutions in village by-laws and overall policy process. The paper concludes by recommending that traditional knowledge and indigenous institutions for sustainable land management 
should be promoted among the younger generations so as to capture their interest, and ensure that successful practices are effectively integrated into the national policies and strategies.

\title{
Keywords
}

\author{
Indigenous Institutions, Natural Resources Management (NRM), Sustainable Land Management \\ (SLM), Traditional Knowledge, Kilimanjaro Region, Tanzania
}

\section{Introduction}

The importance of the Kilimanjaro landscape in providing ecosystem services such as catchment for a range of water uses, local climate modification through the impacts of forest cover, tourism and support for local livelihoods cannot be overstated. However, an extensive process of degradation has seriously threatened the ability of the landscape in providing these services. Land degradation is a major problem in many parts of Tanzania. This problem is largely manifested in the form of severe soil erosion, silting, deforestation and decrease of land productivity. These environmental problems are mainly due to unsustainable agricultural activities, uncontrolled felling of trees for firewood and charcoal, frequent and uncontrolled burning of forests, unsustainable mining activities, overstocking, insecure land tenure and limited community participation in environmental activities. A set of complex and interrelated factors apply, including for example, rapid increase of human population and subsequent reliance on natural resources, land use change, poor land management practices and climate change. The Kilimanjaro Region has thus continued to face a number of environmental challenges including increased pressure on natural resources and subsequent land degradation. Although Tanzania has a comprehensive legal and policy framework for land management, there is a major weakness in sectoral linkages in the policy development and implementation process as well as little participation or integration of traditional rules and regulations for managing the unique features of the ecosystem.

While community groups have traditionally lacked representation in policy development and implementation, there is also little knowledge of the implications of these policies among community groups and how they contradict customary laws and systems of land and natural resource management. This paper presents findings from a study on indigenous institutions and knowledge in natural resources management in project pilot districts in Kilimanjaro Region conducted in November 2013. The paper first reviews relevant literature on indigenous institutions and knowledge in natural resources management. Second, the paper discusses the methodology used in the study in Section 3. This is followed by a presentation of results together with a discussion of these findings. Finally the paper draws conclusions.

\section{Literature Review}

The literature on traditional knowledge has gained rapid currency as researchers and natural resource managers have increasingly considered it as a valuable contributor to natural resource management and biodiversity conservation. Whereas some scholars have questioned what is agreed as indigenous knowledge, key actors and their borders [1] [2], others have debated about the viability of indigenous knowledge as a standalone regime capable of sustaining natural resource management [3] [4]. Although there is currently a general agreement that successful development strategies must incorporate traditional knowledge, controversies still exist particularly in the academic arenas [1]. As a result the terms "indigenous knowledge" and "local knowledge" have largely been used synonymously [5].

While most scholars and practitioners agree on basic issues such as the usefulness of traditional knowledge in the local cultural and environmental settings, what should be explored is the role that the concept of traditional knowledge plays in facilitating or discouraging cross-situational collaboration among actors working for indigenous and non-indigenous institutions of environmental governance such as local natural resources regimes, state agencies working with these regimes and co-management boards [6]. This view fits well in the widely utilized construct of indigenous knowledge which state that:

\footnotetext{
"It is a cumulative body of knowledge, practice and belief evolving by adaptive processes and handed down
} 
through the generations by cultural transmission about the relationship of living beings (including humans) with one another and with their environment" [7].

Indigenous institutions have been defined to include norms and procedures that shape people's actions. These procedures define practices, assign roles and guide interactions. Examples of these traditional institutions include traditional leadership, traditional healers, ritual forests, traditional midwives and various taboos and sacred sites and practices. These institutions play key role in the management of natural resources through different form of indigenous technical knowledge [8] [9]. Both local and other literatures identify three key features that characterize the indigenous resources management: First, the indigenous social organization that controls access to natural resources within the community. Second, the customary norms and procedures for control, acquisition, maintenance and transfer for natural resources and finally, the indigenous utilization techniques for conserving and preserving resources [9]-[11].

Whereas institutions have generally included codes of conduct that define practices, assign roles and guide interactions, these institutions are made up of formal constraints (rules, laws and constitutions), informal constraints (norms, behaviour, conventions and self-imposed codes of conduct) and their various enforcement characteristics [12] [13]. Local institutions differ based on their functions and objectives. They encompass many different types of indigenous organizations and functions such as village-level governance, acceptable methods of community resource mobilization, security arrangements, conflict resolution, and asset management and lineage organizations [14]. It is against this background that the World Bank's framework considers indigenous knowledge as the basis for local decision-making in all aspects of life-food production, education, health, natural resource management and relationships [15].

In comparing the effectiveness of informal and formal institutions in sustainable Common Pool Resources (CPR) management in Sub-Saharan Africa, some scholars argue that informal institutions have contributed to sustainability by creating a suitable environment for joint decision-making, enabling exclusion at low cost for resource users and by using locally agreed sanctions [4]. As informal institutions are embedded in communal structures, they allow the incorporation of the communities' mechanisms and knowledge about the sustainable management and utilization of Common Pool Resources into the Common Pool Resources management [16]. A common pattern in all these cases points to the fact that informal institutions have evolved internally from the society and acted in the interest of the community, which has created a sense of commitment, ownership and responsiveness among the Common Pool Resources users. This in turn contributes to the achievement of sustainability outcomes, particularly prevention of Common Pool Resources degradation and improvement of the Common Pool Resources conditions, in terms of quantity and quality.

The importance of combining indigenous and non-indigenous institutions for land and natural resource management is further reflected in the widespread adoption of international strategies that establish a link between poverty alleviation, sustainable development and biodiversity conservation. The international strategies and initiatives that exemplify this link include but not limited to the Convention on Biological Diversity on Traditional Knowledge, Innovations and Practices, the Ramsar Convention on Wetlands (Resolution IX.21 of 2005-Taking into account the cultural values of wetlands) and the Millennium Ecosystem Assessment (Linking Local Knowledge and Global Science in Multi-Scale Assessments). As such, the recent Global Strategic Plan for Biodiversity (2011-2020) declared in the COP 10 (Strategic Goal E, target 18) that by 2020:

Traditional knowledge, innovations and practices of indigenous and local communities relevant for the conservation and sustainable use of biodiversity, and their customary use of their biological resources should be respected, subject to national legislation and relevant international obligations, and fully integrated and reflected in the implementation of the Convention with the full and effective participation of the indigenous and local communities, at all relevant levels [17].

It is important to note that indigenous knowledge and institutions have their limitations. In some cases these limitations have hindered their integration into the formal system. In fact, even the World Bank's indigenous knowledge framework identifies some of the indigenous practices that are not beneficial to sustainable development (giving examples of slash and burn agriculture to make its point) [2]. Accordingly, it is suggested that despite the strengths, some traditional practices and institutions have weaknesses that may limit their use in management plans that favour sustainability [14]. This calls for the critical examination of the roles, issues and challenges of indigenous knowledge and their institutions in natural resource management governance. 
In the context of Tanzania, literature on traditional knowledge and institutions indicate that prior to independence in 1961, fundamental principles of land access and management were closely linked to chieftainship. Traditional institutions had chiefs as the most respectable law enforcers and the British colonial government recognized the strength of these institutions hence their adoption as native authorities and chiefs as local tax administrators [18]-[20]. However, during the early years of national building, Mwalimu Nyerere considered tribal identities through chiefs as inherently negative and challenging basic principles and objectives of building the national unity [21]. In 1963, just two years after independence, native authorities were abolished and chiefs were officially retired [18]-[22]. Conceptually, the decision to abolish chiefdoms declared their institutions officially inactive across the country.

After the abolition of chieftaincy in 1963 other forms of traditional leadership prevailed and are still effective in some parts of the country. A few communities continued to transfer their traditional knowledge to the new generations due to other reasons including religion and modernity [23] [24]. As the society advances through formal education systems and religious doctrine, children are strictly taught science and God's creations in place of traditions that invoke evil spirits. The raising population and disaggregation of land, rising demands for food and cash, the globalization that commodity land and its resources coupled with the ongoing climate change effects have progressively dissolved traditionally developed values while also strengthening the role of modern institutions over those of the indigenous people [25]. Yet, the informal and formal institutions have their remarkable differences but remain distinctively influential on human behaviour towards sustainable land management [4]. It is suggested that, comparatively, formal institutions have contributed less to sustainable resource management than the informal institutions although under the prevailing situation they are considered important for the implementation of globally agreed strategies for resource management. Based on this narrative, it is argued that formal institutions may indeed have a crucial role to play in sustainable resource management but only if they are equipped with the appropriate power and legitimacy.

The decentralization process that took place throughout most parts of the Third World since the 1990s was a remarkable change that aimed to strengthens formal institutions. In most situations these institutions have contributed less to sustainable resource management due to several factors, including unclear responsibility and power sharing in the decentralization process and their low endurance to change with political conditions. Thus, decentralization has had less effective in achieving the sustainability outcomes in resource management than the informal institutions. Again it is suggested that decentralization could make important contributions in the implementation of strategies and technologies to sustainable resource management if local levels of resource management were equipped with appropriate power and legitimacy [4].

Literature on traditional knowledge and institutions in Kilimanjaro Region and the neighbouring areas of Usambara show that there existed various land-based practices that implemented different traditional measures of land management in different times and for different purposes. Some studies focus on specific uses of land such as for agriculture, water and forest [26]-[31], while few have examined the use of indigenous knowledge in natural resource management generally but for limited geographical locations within the region and the neighbouring areas [8]-[14] and [32] [33]. In these studies, indigenous knowledge and their institutions are generally differentiated from one part of the region to another but a clearer difference is observed when the region is divided into two distinct zones: the Moshi zone in the north (which includes the Municipality, Hai, Rombo and Siha districts) and the Pare zone in the south (which includes Mwanga and Same districts). A good example is noted for the famous practice of intensive land use by intercropping coffee and banana and the combination of this farming practice with forestry and livestock in a sophisticated homestead farm, which is fairly documented but mainly for the Moshi zone [26]. Overall, there is neither study that has comprehensively documented indigenous knowledge and their institutions across the region nor have there been specific focus on Sustainable Land Management. This section is therefore intended to summarize issues that arise from the literature as the basis for assessing and documenting current indigenous knowledge and institutions in the region.

Early expeditions to Kilimanjaro back in the 1880's left Sir Harry Johnston who lead the expedition “amazed by the skill with which the Chagga used tiny channels to irrigate the terraced hillsides and the time spent in turning the soil, manuring it with ashes and raking it with wooden hoes" [27]. It is argued that the system flourished during the colonial period despite a temporary prohibition of furrow construction in 1923. The ban did not last for long as the law was quickly reversed when the British colonial government realized the essential role of irrigated agriculture in the economy [27]. A study which was conducted in 1952 described the Chagga as the most progressive African communities that have been able to produce coffee for the Western world without de- 
stroying their African social structure and system of land tenure [34]. The traditional land management referred to above is connected to the use of water for irrigation as well as intensive land use by intercropping coffee and banana, forestry as well as livestock in a sophisticated homestead farm called "kihamba," which qualifies to be a "complex agrosilvipastoral system". Basically, the kihamba belongs to the clan and is distributed according to the number of members in the extended family including the paternal kin [26].

Studies that have further investigated the role of Kihamba system in land management suggest that in normal conditions, trees planted in Kihamba of one clan could amount to over 40 families including many kinds of herbaceous and woody palms that are either grown or semi-domesticated in the small plots [25] [26]. The mixed cropping of many plants is possible by planting crops of different heights. The description of this mixture is captured well in the passage:

"... as the bottom layer on the land surface is covered with beans, cocoyam, potatoes and a variety of leaf vegetables such as 'loshuci' and 'nyafu', the lower layers between I and 2.5 meters would be filled with arabica coffee, traditional medicine trees, such as the 'iwonu' and shrubs such as 'kweme'. The middle layer is mainly banana trees, yams called 'nduu' or 'iko', fruit trees, such as avocado, and wood for fuel such as 'mduka'. The top layer consists of rather large trees for fuel wood and the highest are timber wood plants. Within this mixture of plants is another component plant 'isale' seen everywhere, is a very important plant for the Chagga as a boundary marker, as a symbol to identify lineage and to warn non-members not to trespass on their land. No one will pass through the places where isale is grown without permission of a lineage member. Furthermore, isale is used as a medicine to care stomach aches” [26].

It is implied in the foregoing passage that although it is generally believed that the use of manure is rare in Sub-Saharan countries (due to shifting cultivation and fire, in which soil fertility is mainly preserved from wood ashes and recovered after fallow), the Chagga have used manure traditionally for centuries in the kihamba system. The leaves of bananas and other trees as well as remains of some crops are spread over the soil surface, which has mulching effects that enhance soil conservation, retain soil moisture and control weeds on the fields.

In addition to kihamba, the Chagga would have a farmland (rema) on the dry plains where maize for the family food, beans for adding variety to family diet and an acre of millet is grown for making mbege to drink and for sale [34]. It is on the basis of this that the Chagga people have developed one of Africa's most impressive traditional systems of water management, which convey water from streams and springs along the steep slopes of river valleys to densely populated interfluves where farmlands are located [28]. This type of water use practice is called the "mfongo" irrigation system [35]. Other studies describe how the water system functioned well prior to "villagisation" when the furrows were still owned and managed by localized lineages [27]. It is also implied that the local control over the furrows ensured the survival of the central traditions governing distribution and maintenance thereby enabling farmers to use the mountain's permanent water resources throughout the year [25]-[28] [35].

Land practices and institutions in Pare (Mwanga and Same districts) did not differ significantly especially in the highlands where farming practices were more or less the same with the Chagga communities. For example, reference to banana grove "nkonde" and irrigation system "nvongo" are similar to the Chagga "kihamba" and the "mfongo" respectively [36]. The hillside groves were managed by mulching with cut banana leaves and intercropping with pumpkins, yams, and beans. However, these techniques could not make up for the gradual loss of fertility and moisture from the sandy red loam soils so each banana grove also received regular inputs of manure and water. As cattle were kept inside the houses, the animals' urine was directed towards the closest banana grove through a special hole at the base of the wall. These irrigation practices are not different from those called "marombo" [37].The tenure and management rights of irrigation water intake were inherited within the lineage of the man who constructed it in the first place, and until recently orders from this manager (the mgawamaji) was respected by the community members. Every farmer who used the irrigation water participated in cleaning and repairing the furrows, and in return the mgawamaji gave them permanent water rights (kiaze) (but no management rights) [36].

Likewise, the land practices that ensured allocation to every male member of family lineage in Chagga applies in Pare. Although this system gave men relatively secure tenure in the past it is also accountable for the rapid fragmentation of farms as the area's population grew throughout the $20^{\text {th }}$ Century [24] [36]. Establishing the rate at which these fragmentations have reduced land area coverage from one land use to another is beyond the scope of this study. However, existing literature support generally that land in the highlands was under the control of 
an elderly male land owner (known locally as mwenyekisaka). Male initiation in sacred forests was a particularly important institution for social control because it provided military training, conferred marriageability, and bound local youths and immigrants into a moral community that had sworn allegiance to the chief. This traditional knowledge transfer system ensured sustainable land and other resource management but it is currently threatened by the rate of fragmentation.

The reviewed literature suggests, on one hand, that informal institutions in Africa did not in themselves offer a long-lasting solution to problems of sustainable land management, particularly in rapidly and dramatically changing environments. On the other hand, however, formal institutions have not managed to address the challenges that have come with modernity hence the need to borrow from and/or revert to the traditional value and rules of resource management. Published evidence from previous studies supports the argument that informal institutions have existed for centuries and have contributed to sustainable land management by mobilizing social capital, solving collective action problems and serving as entry points for interventions in sustainable land management. However, these institutions, particularly for Kilimanjaro, are poorly documented in the existing literature; this has being identified as a gap which called for this study. Although poorly or not documented, traditional practices and institutions have undergone changes that threaten their use for the current challenges of sustainable land management. Yet, there are suggestions that, when compared to formal institutions, informal institutions have a higher potential to survive regardless of the changing socioeconomic and political conditions [31]. Hence, conditions that influence the effectiveness of these institutions need to be identified. These have included, for example, the high rate of population growth and its associated impacts on scarcity of resources, the increasing land use change and the lack of human and financial capacities.

\section{Methodology}

\subsection{The Study Area}

This study was undertaken in Kilimanjaro Region. Kilimanjaro Region is located in the north eastern part of Tanzania. It lies between latitudes $2^{\circ} 25^{\prime} \mathrm{S}$ and $4^{\circ} 15^{\prime} \mathrm{S}$, and between $36^{\circ} 25^{\prime} 30^{\prime \prime} \mathrm{E}$ and $38^{\circ} 10^{\prime} 45^{\prime \prime} \mathrm{E}$. The region shares a common border with Kenya in the north, to the southeast it borders Tanga Region; to the south and west the region borders Arusha Region. Kilimanjaro Region covers an area of 13,209 $\mathrm{km}^{2}$ equivalent to about $1.4 \%$ of the area of the entire Tanzania mainland. Administratively the region is divided into seven districts, namely, Rombo, Mwanga, Same, Hai, Siha, Moshi Rural and Moshi Municipality. Seasonal rainfall distribution greatly influences agricultural practices. In the Kilimanjaro Region, there are two rainy seasons-a major one in April-May and a minor one in September-November, and two dry seasons, a major one in December-January and a minor one in July-August. There is marked variation in the amount of rainfall according to altitude and the direction of the slope in the mountainous areas. The mean annual rainfall varies from $500 \mathrm{~mm}$ in the lowlands to over $2000 \mathrm{~mm}$ in the mountainous areas (over 1600 meters above sea level). Temperatures are closely related to altitude. During the rainy season, extra cloud cover and evaporative cooling tend to reduce maximum temperatures. Cloud cover also tends to raise minimum temperatures. The hot season lasts from October-March with high humidity; temperatures going up as far as $40^{\circ} \mathrm{C}$ in the lowlands. In the mountainous areas temperature ranges from about $15^{\circ} \mathrm{C}-30^{\circ} \mathrm{C}$.

According to the 2012 National Population and Housing Census, the region had a population of 1,640,087 [40]. For 2002-2012, the region's average annual population growth rate was 1.8 percent, which ranked $24^{\text {th }}$ highest in the country. It was also the eighth most densely populated region with 124 people per square kilometer [38]. Although the region could be described as one of the densely populated regions in the country it is worth noting that the population is unevenly distributed. The highlands are the most populated areas with an average of 600 persons $/ \mathrm{km}^{2}$. Likewise the intermediate zone, which lies between 900 - 1100 meters above sea level, has a high population density of 250 persons $/ \mathrm{km}^{2}$. At district level, Rombo and Moshi Rural districts are the most populated with 160 and 256 people persons $/ \mathrm{km}^{2}$ respectively [38]. The population distribution pattern in the region is by and large influenced by soil fertility. This explains the reason for concentration of the population in the highland areas. In addition, environmental degradation is increasingly taking place due to poor farm management system such as non-use of soil erosion control methods. In this regard, the region needs to intensify land management practices in order to improve land productivity per unit area. Generally the experience of land limitation is the factor which mostly contributes to the movement of people out of the region. 


\subsection{Sample Size and Sampling Procedures}

The selection and determination of sample size was based on the information obtained from the project office, particularly in relation to the number of villages in the project area. The District Focal Persons provided some useful information on villages located in high, middle and lower strata. In order to attain a $90 \%$ confidence the required minimum sample size for the entire region was estimated to be 164 households. This gave us an estimation error of $5 \%$ (the difference between the actual and estimated parameter value). The sample size was obtained using the following expression [39].

$$
n_{o}=\frac{z_{\alpha / 2} p(1-p)}{d^{2}}
$$

If we take $90 \%$ confidence interval, the $z_{\alpha / 2}$ is 1.28 , if we assume the difference between the actual value and estimated value of the parameter is 5 percent and if we assume the proportion of households involved in the natural resources management in Kilimanjaro Region is 50 percent, then the required sample size will be approximately

$$
n_{o}=\frac{1.28^{2} \times 0.5 \times 0.5}{(0.05)^{2}}=164 .
$$

In each selected ward or village a total of 30 households were supposed to be selected and interviewed, however, there were variations in the number of households interviewed per ward or village in each district due to availability of respondents in the selected villages. A total of 221 households were interviewed for the household questionnaire as follows: There were 27 households interviewed in Rombo, 29 in Hai, 29 in Siha, 30 in Same, 30 in Mwanga, 31 in Moshi Rural and 45 in Moshi Municipal.

The heads of the households were the ones who were targeted to be interviewed but if they were not available during the survey other members in the households were interviewed. Heads of households were interviewed because it is believed that they have information regarding the households' composition. The data set shows that most of the respondents were heads of households (76\%) followed by spouse (20.8\%), children (2.7\%) and other relatives $(0.5 \%)$.

On the sampling procedures, there were two levels of sampling; one for the villages and another for the households in the selected villages. Sampling for quantitative part of the study was guided by the existing stratification of villages in the Sustainable Land Management project area. Since there was already an established stratum that the project uses in other studies, a Stratified Random Sampling design was therefore used on the basis of the existing strata, which are Upper, Middle and Lowlands for Rombo, Hai, Siha, Mwanga, Same and Moshi Rural District; Eastern, Central and Western for Moshi Municipality. A total of 25 villages (approximately 3 from each district) were randomly selected, using computer-generated random numbers, for the study. One village was randomly selected from each stratum in the catchment area. Respondents were selected from all the districts in Kilimanjaro Region according to whether they are in the upper, middle or low land areas. According to stratification criteria used one village or ward was selected in each stratum per district.

Qualitative data was particularly important in this study due to the nature of the study. There were different sources and procedures to acquire qualitative information. It is important to note that not everybody possessed, understood and practiced the knowledge that we sought to assess and document. Therefore purposive sampling design was used to select people who could provide the required information on traditional knowledge and practices of natural resources management in Kilimanjaro Region. These people were elderly people, religious and traditional leaders, healers, representatives of development partners, NGOs, government officials etc. In addition, a snowball sampling techniques was used to locate other members who possessed traditional knowledge on natural resources management. Through these two methods, the research teams managed to ask those individuals to provide the needed information on traditional knowledge and practices in natural resources management. In this regard, the number of people contacted was determined by the information saturation.

\subsection{Methods}

Both qualitative and quantitative methods were used to collect data from different sources. While some of these sources were primary sources, other sources were secondary, that is, government policies and laws, project documents and published research materials on the subject. Different techniques were used to collect qualitative 
information. These included 41 in-depth interviews held with key informants. In addition, a total of 24 FGDs were conducted with groups of traditional farmers, pastoralists, water users, bee-keepers, forest and wildlife user groups and village councils. Group composition ensured gender representation (women, men, youths and special groups). A questionnaire was designed to capture the information related to general understanding of villagers on indigenous knowledge, the status and use of indigenous knowledge, how the existing policies and laws integrate (or do not integrate) and important issues of the knowledge that could facilitate Sustainable Land Management. The questionnaire had both structured questions and open-ended questions

Data analysis was focused on understanding of traditional knowledge and indigenous institutions on sustainable land management. Therefore qualitative information from focus group discussions and in-depth interviews were transcribed and analyzed to see what themes would emerge. The qualitative data contributed to the overall developing picture on natural resources management in Kilimanjaro Region. Quantitative data from the household questionnaire was computer processed using the Statistical Package for Social Science (SPSS) programme version 21. Frequency distribution and cross-tabulations were used to compare different variables within and across the study sites. Where relevant the Pearson Chi-square statistics was used to test the significance relationships between comparable variables.

\section{Results and Discussions}

\subsection{State of Traditional Knowledge on Sustainable Land Management}

This section assesses the state of local knowledge on sustainable land management in various districts in Kilimanjaro Region, by addressing issues related to awareness of traditional knowledge and practices, state of traditional knowledge and practices, custodians of traditional knowledge, ways of acquiring traditional knowledge and practices, role of gender relations and changes on traditional knowledge and practices.

\subsubsection{Awareness of Traditional Knowledge and Practices}

In order to establish levels of understanding of traditional knowledge on sustainable land management, respondents in the study areas were asked to state whether they were aware of various traditional knowledge and practices related to sustainable land management. Majority of respondents (93\%) indicated to be aware of those practices, while the remaining $7 \%$ were not aware (Table 1).

As shown in the table, respondents in Same, Siha, Mwanga, Hai and Rombo districts were more aware of the traditional methods and practices of sustainable land management than those in Moshi Urban District. Respondents in Same, Siha, Hai, Mwanga and Rombo districts were more aware of the traditional methods and practices than those in other districts due to fact that these districts are rural based and therefore still practice some of these traditional methods and practices. Secondly, these districts often experience droughts during dry seasons and landslides and soil erosion during rainy seasons, conditions that have impelled communities in those districts (Same, Siha, Mwanga, Hai and Rombo) to adopt more sustainable land management practices.

The level of awareness of traditional knowledge and practices of sustainable land management was not significantly different between respondents of different education levels. However, there were considerable

Table 1. Percent response on awareness of traditional methods and practices of sustainable land management in Kilimanjaro Region by district.

\begin{tabular}{cccc}
\hline District & Number of respondents & \multicolumn{2}{c}{ Aware of traditional methods of SLM } \\
\cline { 3 - 4 } & 30 & Yes & No \\
Same & 29 & 100 & 0 \\
Siha & 30 & 100 & 3.7 \\
Mwanga & 29 & 96.7 & 3.4 \\
Hai & 27 & 96.6 & 3.7 \\
Rombo & 31 & 96.3 & 11.9 \\
Moshi rural & 45 & 90.3 & 20.0 \\
Moshi urban & 221 & 80.0 & 6.8 \\
Total & 93.2 & 93.2 \\
\hline
\end{tabular}

Source: Compiled from Field Work Data, November 2013; $\left(\mathrm{X}^{2}=22.731\right.$, df $\left.=12, \mathrm{p}<0.030\right)$. 
differences between gender groups. It was noted that more male (59\%) respondents were aware of the traditional methods and practices of sustainable land management compared to $41 \%$ among female respondents. The difference in awareness of the traditional methods and practices of sustainable land management between male and female respondents was statistically significant $\left(X^{2}=6.56, \mathrm{df}=2, \mathrm{p}<0.038\right)$. The main reason for the observed trend was that customarily, men are the ones who inherit land in Kilimanjaro Region, and thus have more keen interest in conserving the land than women. It was noted for instance that "Women are strictly restricted from going to water catchment areas with their clay water pots so as not to pollute water in catchment areas" (in-depth interview). This indicates the use of threats and taboos so as to conserve water catchments.

While there has never been any evidence of pollution, this has customarily been practiced with the aim of protecting the respective water sources. The inadequate engagement of women in resource management is also echoed by other studies in Kilimanjaro Region. For instance, Magigi and Sathiel [40] reported that despite progress on various initiatives to mainstream gender in development initiatives, equality, ownership and use of resources have been minimal in developing countries, resulting into decreasing local economic development, food security, ecological integrity and sustainable livelihoods.

Further analysis indicated that there are variations on the awareness of traditional methods and practices of sustainable land management by age groups. Respondents aged 46 years and above appeared to be more aware of traditional methods and practices of sustainable land management than other age groups. These differences in awareness between respondents of different age groups could be explained by the fact that more people $(77.7 \%)$ aged 46 years and above have more experience with traditional methods and practices, and often considered as the custodians of culture of the various ethnic groups. On the other hand, people aged 17 - 35 years and those aged 36 - 45 years are mainly youths who have spent most of their lives in schools and therefore least attached to land management issues and have the least developed interest and commitment to land management matters.

Figure 1 presents the sources of traditional knowledge in Kilimanjaro Region. While a considerable proportion (54.8\%) did not mention to use traditional knowledge/practices, it is evident that those who use it have learnt about it from elders and other villagers (52\% and 29\% respectively). It is clear from Figure 1 that traditional practices are rarely learnt from government officials and/or conservation projects and organizations as indicated by the small proportions of respondents, but rather from peers and elders. For enhanced sustainability in land management therefore there is a need for more integration of the relevant traditional knowledge systems and practices with land related policies and governance systems.

\subsubsection{Existing Traditional Knowledge and Practices}

Table 2 summarizes various traditional knowledge and practices in various study sites as explained during in-depth interviews and focus group discussion. Table 2 reveals that in all the study sites traditional knowledge and practices are applied in sustainable land management and people have considerable understanding of these methods as exemplified by different respondents during in-depth interviews.

1) Cultivation ridges and traditional irrigation canals

Indeed, the study revealed the existence of many traditional practices of sustainable land management in the Region. Among these included the use of cultivation ridges (Matuta) along the slopes (Figure 2). Figure 2 also shows the water canal constructed for irrigation as well as for reducing soil erosion. These old practices of controlling soil erosion were enforced by traditional leaders, or Chief. Historically, everybody was required to do so in slopes. However, it was claimed by farmers during this study that this practice is currently used on a limited scale due to lack of manpower and inadequate knowledge and interest among the youths to construct terraces. These reasons may be associated with modernity which has kept the young generation in schools and much away from farm activities.

2) Tree planting

Tree planting in homesteads and farms is another long tradition which is still practiced today (Figure 3). There are trees that have traditionally been identified for their significance in land protection, provision of shades, water retention, prevention of soil erosion, border demarcation and some have symbolic importance for various cultural practices. Through traditional knowledge of identifying areas that were threatened by problems like landslides, the community would protect such lands by planting trees. As captured in Figure 3, these areas are mostly those along water ways (locally known as mkondowamaji) that happen to be in farms.

Overtime, however, changes have occurred in terms of the number and type of these trees. In terms of numbers, the growing human population and subsequent increase in settlements have reduced the areas available for 


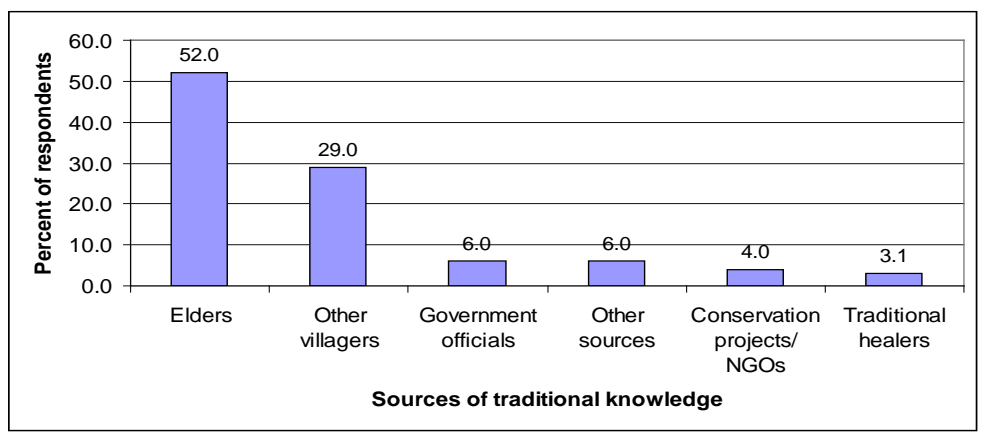

Figure 1. Percent response on where respondents learn about the traditional method/practices.
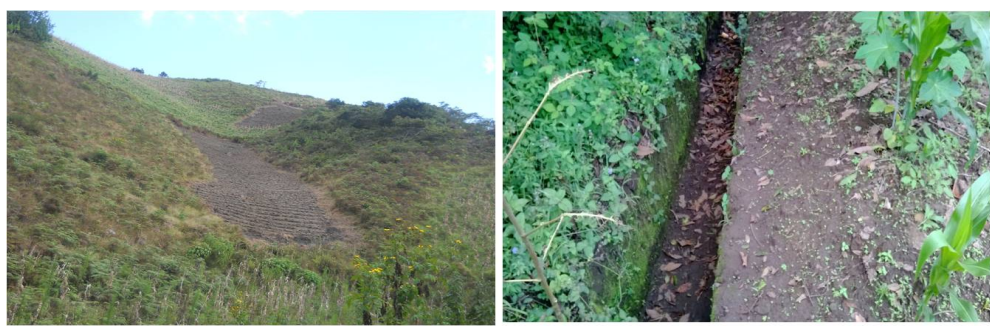

Figure 2. Ridges along the slope of the mountain in Lokiri Village in Siha District (left), and traditional irrigation canals (right).

Table 2. Various traditional knowledge and practices in the study sites.

\begin{tabular}{|c|c|c|c|}
\hline $\begin{array}{l}\text { Name of traditional } \\
\text { knowledge and practices }\end{array}$ & Local terminology & $\begin{array}{l}\text { Type of resource } \\
\text { managed }\end{array}$ & Area of operation \\
\hline $\begin{array}{l}\text { Construction of terraces } \\
\text { by using stones }\end{array}$ & $\begin{array}{l}\text { “Maporomoko” in Pare } \\
\text { language or land slide }\end{array}$ & Soil & Mwanga and Same study sites \\
\hline $\begin{array}{l}\text { Allocating forests for } \\
\text { ritual ceremonies }\end{array}$ & $\begin{array}{l}\text { "Mitaso” in Pare language or places for } \\
\text { performing rituals to appease the dead }\end{array}$ & Forest and water & $\begin{array}{l}\text { Rombo, Same and Mwanga } \\
\text { study sites }\end{array}$ \\
\hline $\begin{array}{l}\text { Fines in kinds (cow, goats } \\
\text { or sheep with honey beer) }\end{array}$ & $\begin{array}{l}\text { "Mahaani” in Pare language } \\
\text { or fines in kind }\end{array}$ & $\begin{array}{l}\text { Water, soil, forests } \\
\text { and other resources }\end{array}$ & $\begin{array}{l}\text { All study sites (Rombo. Hai, } \\
\text { Same, Mwanga, Moshi rural) }\end{array}$ \\
\hline $\begin{array}{l}\text { Reforestation by planting local } \\
\text { trees (Mifumo and Mikuyu) }\end{array}$ & “Panda miti” or reforestation & $\begin{array}{l}\text { Soil, water } \\
\text { and forest }\end{array}$ & $\begin{array}{l}\text { All study sites (Rombo. Siha Hai, Same, } \\
\text { Mwanga, Moshi rural \& Moshi urban) }\end{array}$ \\
\hline $\begin{array}{l}\text { Both fallowing by leaving } \\
\text { the land idle to regain fertility }\end{array}$ & “Kulazashamba” or fallow & Soil & $\begin{array}{l}\text { All study sites (Rombo. Siha Hai, Same, } \\
\text { Mwanga, Moshi rural \& Moshi urban) }\end{array}$ \\
\hline Ant poaching & $\begin{array}{l}\text { "Ngoloshoi” in Chagga language } \\
\text { or prohibition of poaching }\end{array}$ & Wildlife & Siha, Hai, Rombo and Same study site \\
\hline Beekeeping & & Forest & Siha, Mwanga, Rombo and Same \\
\hline Threats and taboos & & Water and forest & $\begin{array}{l}\text { All study sites (Rombo. Siha Hai, Same, } \\
\text { Mwanga, Moshi rural \& Moshi urban) }\end{array}$ \\
\hline $\begin{array}{l}\text { Strip terraces and planting } \\
\text { guatemala graces }\end{array}$ & & Soil & $\begin{array}{l}\text { All study sites (Rombo. Siha Hai, Same, } \\
\text { Mwanga, Moshi rural \& Moshi urban) }\end{array}$ \\
\hline Construction of ridges & $\begin{array}{c}\text { “Matuta or Mfuloi” for Chagga } \\
\text { language or ridges }\end{array}$ & Soil & $\begin{array}{l}\text { Moshi rural, Siha, Hai and } \\
\text { Rombo study sites }\end{array}$ \\
\hline Growing grasses and Trees & $\begin{array}{c}\text { "Ihaninyika” in Pare language } \\
\text { or indigenous forest }\end{array}$ & Soil & $\begin{array}{l}\text { Moshi rural, Siha, Hai and } \\
\text { Rombo study sites }\end{array}$ \\
\hline
\end{tabular}

Source: Compiled from Field Work Data, November 2013.

tree planting hence fewer trees can be grown around the homesteads. An elderly respondent commented, for example, that on average 4 - 5 households have established settlements in only one acre compared to one household in the past years. In this case, land for tree planting is limited across much of the region especially in 


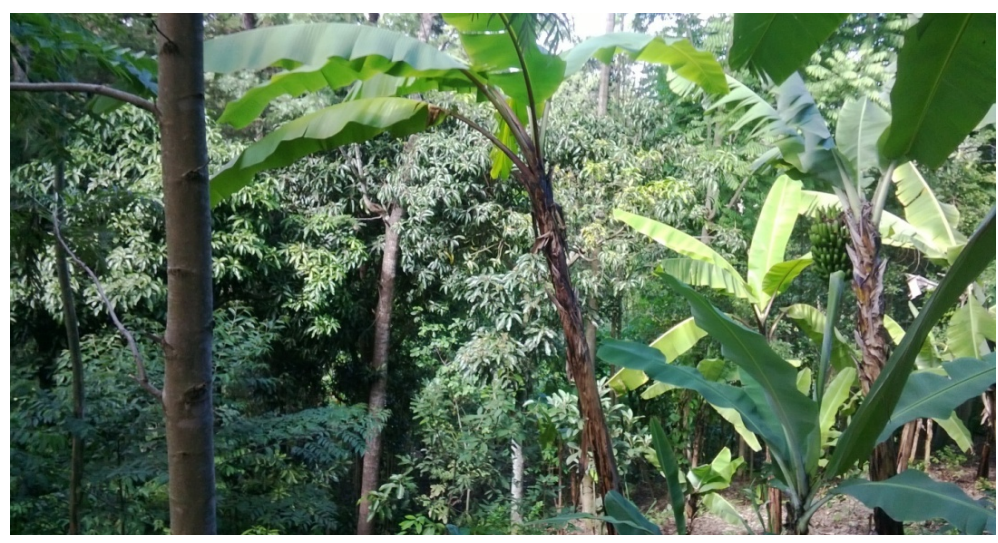

Figure 3. A homegarden at Ibukoni Village, Rombo District.

the highlands and midlands. Among other challenges associated with tree planting was the complaint from farmers following the ban by the government through the regional administration to cut trees without permit from the District authorities. Because of the above situation, people are currently reluctant to plant trees as they are arguing that there is no need to plant a tree which you cannot harvest when you need to do so.

It is important to note also that trees are part of family assets and an important source of cash incomes. It is in this connection that there is high monetary value for forest products, which continue to be an impetus for deforestation. Although the government regulates harvesting of some tree species and that people are required to obtain permits from village offices for cutting trees, illegal activities continue due to corruption and the inadequate law enforcement. Notable timber products of threatened species still have readily available markets.

3) Use of farmyard manure

The use of farmyard manure (samadi or Boru) is common in Kilimanjaro Region. Manure comes from livestock wastes and is one of the important traditional methods of agricultural land management particularly in Rombo District. It is a most common practice especially where stall feeding of livestock is practiced. Although this is still practiced to date, respondents acknowledged that there are growing challenges of stall feeding as more open areas that were a source of fodder are either turned to settlements or access is restricted by the government (especially in forests). Following these restrictions, animal rearing specifically cattle is increasingly becoming expensive because famers have to buy the fodder. Some respondents suggested also that there has been reluctance in using boru generally due to the availability of industrial fertilizers which are easy to handle compared to farmyard manure. Boru comes from livestock wastes. Narratives indicated also that other kinds of livestock wastes (chicken and goats) are mixed with ashes and filled in bags and kept for some 20 - 30 days to decompose after which it is distributed to the farm. This was reported to be not only very effective in increasing soil fertility but also the ashes have repelling effect for some insects which cause damage to understorey plants in the home gardens.

4) Mulching

Mulching (locally known asmasoro) is another traditional and common practice in Kilimanjaro Region. It is usually done using crop residues and remains from livestock feeds, farm, tree leaves from different kinds of mixed plants farmland, which together make an excellent mulch (Figure 4). This method has been used over generations. The importance of this practice is that the mulch covers the top of the soil hence preventing it from direct sunshine and runoff. This tradition helps to retain soil moisture while increasing fertility after decomposition of the mulch, and protects the soil from erosion by reducing surface runoff.

5) Mixed cropping

Mixed cropping is another old tradition which is based on kihamba farming system where many kinds of crops are grown in same plots. In the past the diversity of plants in the kihamba was very high and could amount to 42 families [41]. However, currently there are very few farmers with the kind of mixed cropping recorded in the past. In the present study, only a few such plots with dense mixed cropping were observed which may be interpreted to represent a general failure of kihamba farming system.

6) Rotational cropping/fallowing

Rotational cropping/fallowing is another traditional practice of conserving the land in many parts of 

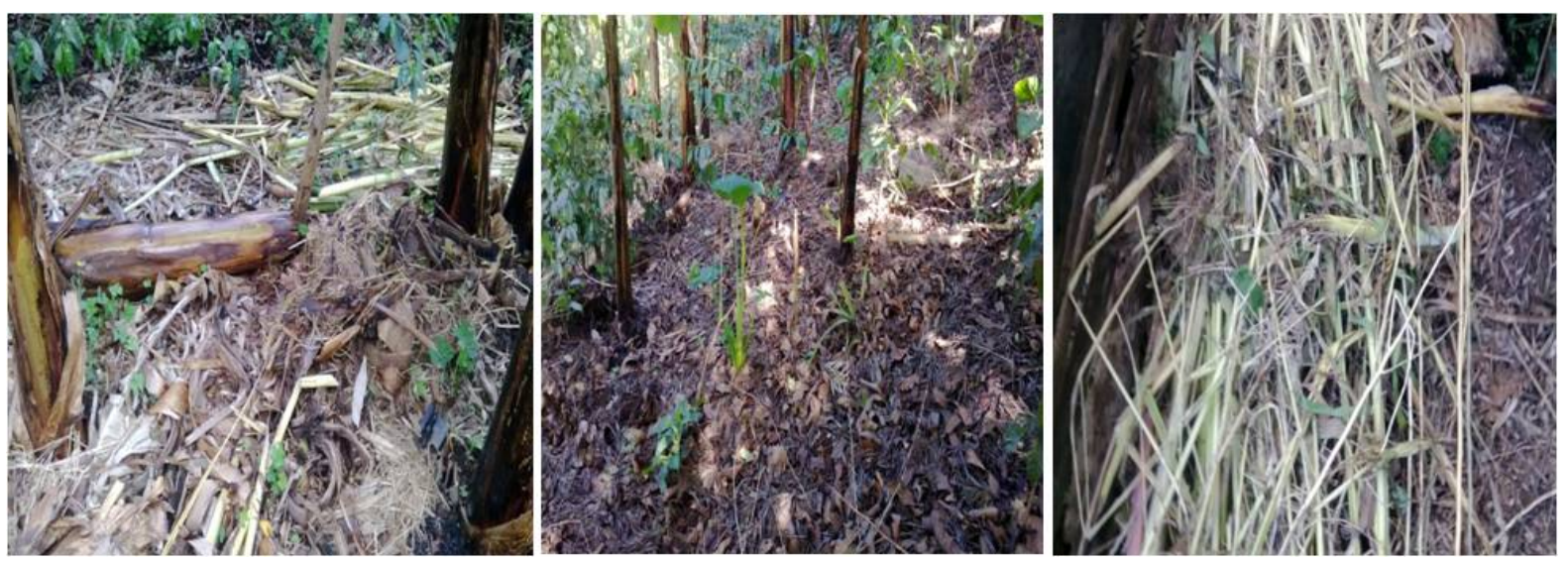

Figure 4. Mulching (masoro) in Rombo District.

Kilimanjaro Region. However, the increasing pressure on land associated with population growth has in many places made rotational cropping and/or fallowing generally not feasible. Consequently same fields are continuously being cultivated resulting in soil degradation and decreased productivity [42]-[45].

The role of mixed cropping has generally been to increase organic manure in the soil, creating shades that assist in soil water retention and preventing soil erosion among other things. These are all basic principles of sustainable land management that communities have attached to their culture and traditions for generations across much of the slopes of Mt. Kilimanjaro. These practices have been effective in protecting the land while also ensuring the availability of varieties of food crops. As changes in culture and traditions continue due to various reasons, including modernity, these practices have also changed over time.

7) Protection of some species by the chiefs

As it is with the government today, whereby certain species are protected and may not be utilized without permission, even in the past some species were ownership and protected by the local chief. Traditional leaders such as chiefs claimed ownership of certain species of plants and animals hence other members of the community would not be able to use these species. By their royal status these species were therefore protected wherever they were found in the chieftaincy. Table 3 presents some of the species and others that have benefited from traditional knowledge of their significance. Notwithstanding their importance to the community and the environment, most of these tree species are locally perceived as currently extinct or threatened with extinction.

8) Use of intimidations, threats and taboos

Intimidations, threats and taboos have traditionally been used to conserve various resources. The uses of intimidations and taboos were based on the prior knowledge of the importance of particular resources. Specifically, traditional leaders introduced taboos to protect water catchments and plants around these catchments. Most of these taboos were meant to intimidate people so that they do not haphazardly harvest these species. Among the taboos recorded in this study were narratives about the presence of big snakes and/or demons in certain trees; women not allowed to reach certain areas of catchments; some trees crying if they were cut which was interpreted to signify bad lack for whoever did it. These taboos created fear and respect to certain places and species by community members. In the case of women, they are the firewood collectors hence preventing them from going to water catchments ensured that these catchments remained intact.

It was claimed, for instance, that in conserving forests among the Pare it is common to find threats like "Any person who cuts firewood or trees in a forest conserved for rituals and thanksgiving purposes or in water catchment areas will be fined a cow, goat or sheep with honey beer depending on the intensity of destruction he/she had made". This shows that various sanctions are inbuilt in traditional knowledge and practices and have for generation been effectively used to conserve the local resources in various communities.

In an interview with an elderly man (95 years) in Rau Ward, Moshi Municipality, as part of the present study revealed how traditional knowledge can be used in the interpretations of current environmental changes such as changes in climate and shortages of water and low soil fertility, associating them with the failed traditional resource management systems.

“... this mountain that you see was not climbed by everyone like it is now. It had very special use and 
Table 3. Traditionally protected species and their significance.

\begin{tabular}{|c|c|c|c|}
\hline Local name & Botanic name & Importance & Current status (local perception) \\
\hline Mvule & Milicia & $\begin{array}{l}\text { Chief's tree (Mtiwamila)—with total protection. } \\
\text { Only Mangi could use it. Used for sacrifices }\end{array}$ & Threatened with extinction \\
\hline Mgangafumu & & Chief's tree (Mtiwamila)—with total protection & Locally extinct \\
\hline Misesewe & Albiziaglaberrima & Shade, water retention & $\begin{array}{l}\text { Threatened with extinction-they are } \\
\text { replaced by timber species. Also, they } \\
\text { are currently targeted for white timber }\end{array}$ \\
\hline Masale & Trigonellafoenum & $\begin{array}{l}\text { Prevent soil erosion, reduce conflicts } \\
\quad \text { (is a respected border mark) }\end{array}$ & $\begin{array}{l}\text { Still maintains its traditional } \\
\text { values but are few }\end{array}$ \\
\hline Mfumu & Vitexdoniana & Water retention & Threatened with extinction \\
\hline Mruka & Alfzeliaquanzensis & Shade, water retention and prevent soil erosion. & Threatened with extinction \\
\hline Mapala & $\begin{array}{c}\text { Acer } \\
\text { pensylvanicum }\end{array}$ & $\begin{array}{c}\text { Prevent soil erosion and are evergreen } \\
\text { throughout the seasons }\end{array}$ & Threatened with extinction \\
\hline Mapasa & Mcobotini & $\begin{array}{l}\text { Prevent soil erosion. Are planted as } \\
\text { fences across steep slopes }\end{array}$ & Threatened with extinction \\
\hline Mkuyu & Ficussycomorus & Water retention & Threatened with extinction \\
\hline Mringaringa & Acacia albida & Water retention & Threatened with extinction \\
\hline Mihanzi & Albus & Water retention & Threatened with extinction \\
\hline $\begin{array}{c}\text { Masteria, Majaniyatembo, } \\
\text { makatimara and } \\
\text { makengera }\end{array}$ & $\begin{array}{l}\text { Diplurida/ } \\
\text { arachnida }\end{array}$ & $\begin{array}{l}\text { Control soil erosion but also } \\
\text { nutritious animal feeds }\end{array}$ & Threatened with extinction \\
\hline Mnengu & Hymenaeaverrucosa & $\begin{array}{l}\text { Moisture retention-hosts some insect species } \\
\text { (called firondo) that emit water during dry season }\end{array}$ & Threatened with extinction \\
\hline
\end{tabular}

Source: Compiled from Field Work Data, November 2013.

therefore only chosen people from the community, mainly men, could climb to practice offerings for propitiate the spirits of the dead (matambiko). This was mainly accompanied with slaughtering of goats and cows, pouring of milk and honey. An exception could only be made when there was a need for special sacrifice and a young woman could be taken [for sacrifice]. As these men descended after offerings, they would clean water furrows all the way down. Indeed, by the time they arrive home it would have rained and the water would have a clear path to follow" [46].

Although the importance of sacrifices in causing rainfall and water availability is contestable, the narrative above suggests that some of the traditional practices were useful in conserving the mountain forests, clearing and maintaining water furrows. This ensured catchment protection and reduced land degradation that could result from the lack of clear paths for water. Two kinds of challenges exist today. One, there is no longer a well-organized system of water distribution to farms by elderly people (the "Mfongo" institution). The interviewed elderly men who used to distribute water to people's farms indicated passion and trust in the institution yet they confessed that the system broke in their hands for failing to transmit the knowledge to the young people.

The second challenge relates to the fact that some of the government-led resource management strategies that seek to upgrade traditional practices contribute to their destruction. Examples were given, for example, the use of cement in concretizing some of water sources and furrows that are threatened by degradation. Participants in FGDs in Rau Ward were of the view that modern methods of sustainable land management do not necessarily produce good results. In Rau, for example, a once-off sponsorship that was secured through local politicians made concrete walls for the main furrow and replaced elephant grasses that had been planted for long along the banks. In a span of only four years, the wall broke and since then there was no any renovation plan, the water force has increased hence causing land degradation than it was before.

\subsection{Factors for Changes in Traditional Knowledge and Practices on Natural Resources Management}

This study examined factors for changes in traditional knowledge and practices on land, forest, water and wild- 
life management. Results from focus group discussions and in-depth interviews in the study sites indicated that community members have been observing the changes on knowledge and practices on natural resources (land, forest, water and wildlife) management over time. The main reasons explained by respondents revolved around the spread of modern oriental religions (Christian and Muslim), which all are against traditional beliefs, population growth due to demographic processes of increase in fertility and net immigrations which have increased high demand of resources leading to reduction of arable land and grazing land, protected forests, and forests, and water catchment areas which were all formally protected.

The increase in family size has led to population pressure on the existing land thus the existence of a miss-match between number of people and the available resources. Another reason mentioned for these changes was the climatic changes which have caused many water sources to dry. In addition is the eradication of the traditional leaders which based on chiefdoms and their replacement by government leadership, such as ten cell leaders, sub village chairpersons, and village chairperson, have contributed to the decline of many traditional practices.

The other factor regards the methods of acquiring traditional knowledge and practices. Various methods of acquiring traditional knowledge and practices were mentioned by respondents in the study areas. Through focus group discussions and in-depth interviews participants mentioned field training by members of families/clans, traditional meetings, ritual ceremonies, Government expertise like extension officers and forest agencies as among the different methods used to acquire traditional knowledge and practices. It was noted during a focus group discussions and in-depth interviews "When young boys are passed from boyhood to manhood in ritual ceremonies they are taught how to conserve the environment, how to handle wives and children; they have to learn from the previous knowledge”. This indicates that young boys are taught to handle the land resources during ritual ceremonies. However, as noted earlier in the paper, most of the you generation spent most of the young age at school with very limited touch to livelihoods in the rural setting, which to a large extent make them to miss such training.

Furthermore due to globalization and interactions between different communities traditional customs are no longer practiced all the times, for example, ritual ceremonies in some societies especially in urban centers do not exist any longer. According to elderly people interviewed during focus group discussions and in-depth interviews, reinstatement traditional knowledge specifically through ritual ceremonies could be the only way to ensure that traditional knowledge on sustainable land management is passed from one generation to the other.

\subsection{Indigenous Institutions for Natural Resource Management}

An inquiry was made regarding the respondents' awareness of the existence of indigenous institutions for sustainable land resource management in their areas. Responses indicated that $62.0 \%$ were aware, while the remaining 38.0\% of respondents were not aware (Figure 5). Findings in Figure 5 indicate responses differed from one district to another with Same and Siha having largest proportions of respondents reporting of awareness. The level of awareness of these institutions is, in this case, closely related to two things; first is how the community is culturally organized and, second, the kind of land management challenges that communities have faced for generations. Accordingly, it is possible that Same and Siha districts have more land management challenges hence the high levels of dependence on traditional practices and institutions.

Quantitative data suggest that there is a clear understanding of the difference between traditional and modern institutions and that the percentage of respondents indicating awareness of the existence and importance of indigenous institutions is relatively high (64\%), as compared to $36 \%$ reporting to be unaware. Nevertheless, this level of awareness is not directly related to the current levels of reliance on indigenous institutions of land management. Practically, most respondents made reference to indigenous institutions that have existed in the past and those that are only marginally used at the moment. Reference to the past institutions is clearer when subjected to content analysis. Qualitative data suggested, for example, that the use of indigenous institutions has been interfered by modernity in its different forms including through modern religions and schools, reliance on market economy which has encouraged importation of industrial products such as fertilizers and the democratic governance that allow the majority decision to rule even in matters that have traditionally been managed through cultural norms and beliefs. As a result, the young generation is less aware of both the practices and indigenous institutions. For example, Table 4 demonstrates that youths between the ages of 17 - 35 years who participated in the study were 26 and majority of them (65.3\%) were unaware of any indigenous institutions. As such, this 


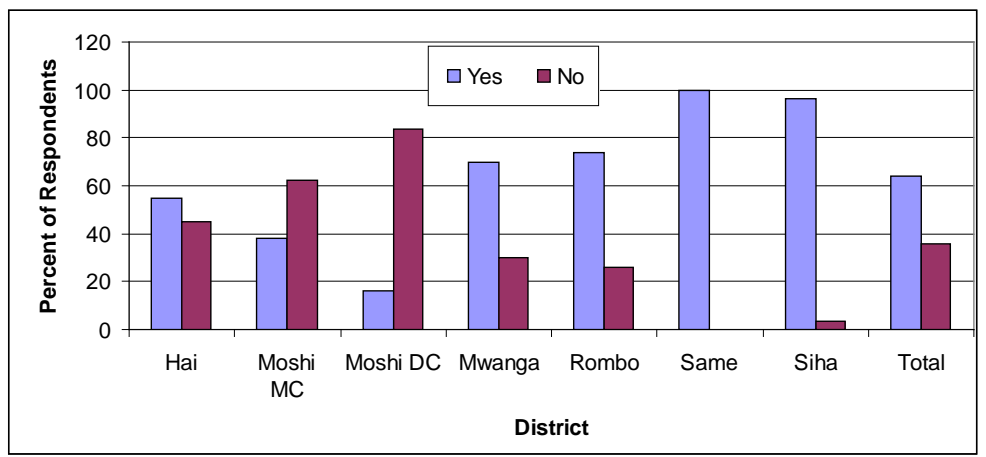

Figure 5. Percent responses on awareness of indigenous resources management institutions.

Table 4. Awareness of indigenous institutions by age group.

\begin{tabular}{cccc}
\hline Age group & Yes & No & Total \\
\hline $17-35$ & 34.7 & 65.3 & 100 \\
$36-45$ & 65.6 & 34.4 & 100 \\
$46+$ & 65.7 & 34.3 & 100 \\
Total & 62.0 & 38.0 & 100 \\
\hline
\end{tabular}

Source: Compiled from Field Work Data, November 2013.

knowledge is mostly held by the age of 36 years and above as demonstrated by more than $65 \%$ of respondents in each age group who reported to be aware of indigenous institutions. Pearson Chi-Square test also confirmed that there is a significant relationship $\left(X^{2}=17.221, \mathrm{df}=4, \mathrm{p}<0.002\right)$ between the level of awareness of indigenous institutions and age of respondents. This means that as age increases, awareness of indigenous institutions also increases. According to this data, modern institutions are currently better known by the younger generation, which suggest that the transfer of this traditional knowledge has been constrained by various factors as discussed elsewhere in the paper.

Table 5 shows the responses on the types of land management institutions. It is clear from the Table 5 that there has been a mix between traditional and modern structures of these institutions. However, according to the respondents, family/clan organizations, traditional leaders, followed by the legacy of Mangi chieftainship, are the main indigenous institutions dealing with land management issues in the area. Other indigenous institutions are the resource user groups and community-organized security (known locally as Sungusungu). It should be noted however that the existence of these institutions cannot be generalized for all the districts. In Same district, for instance all the identified indigenous institutions exist, suggesting that there may be little or no use of modern institutions. This trend is also noted in the neighbouring Mwanga District. The impression created by the two districts is that reliance on indigenous knowledge and institutions is motivated by the type and intensity of problems that exist in the respective society. A similar argument was reported by [40]-[45]. Indeed, the two districts share similar landscape characteristics that might explain challenges in land management hence their continued dependence on these indigenous institutions.

Although Table 5 presents both indigenous and modern institutions of land management as understood by respondents, the focus of this section is on indigenous institutions. In the following we present brief accounts of the current status and relevance of these indigenous institutions based on the collected quantitative and qualitative data.

\subsubsection{Families/Clan Organization}

This type of institutions was found across the districts with Same and Mwanga having the highest number of respondents who recognized family/clan organization as an important institution in sustainable resource management at the local level. Whereas in these districts these organizations are known by clan names (for example, Wamwanga and Wafinanga), family organizations in the rest of the region have mainly made reference to the kihamba system. Although there is a slight difference across the districts, the point of convergence for these 
Table 5. Percent response on indigenous institutions by district.

\begin{tabular}{cccc}
\hline Indigenous institution & & \multicolumn{1}{c}{ Modern institution } \\
\hline Name of institution & $\begin{array}{c}\text { Percent of } \\
\text { respondents }\end{array}$ & Name of institution & $\begin{array}{c}\text { Percent of } \\
\text { respondents }\end{array}$ \\
\hline Family/clan organization & 74.9 & Cooperative societies (KNCU, Kibong'oto Wandri) \\
Traditional leadership & 64.9 & Village environmental committee \\
Mangi chieftainship & 49.6 & Government/Extension officers & Village land council \\
Social and resource user groups & 27.9 & Don't know \\
Community-organised security (Sungusungu) & 2.2 & 30.2 \\
\hline
\end{tabular}

Source: Compiled from Field Work Data, November 2013.

organizations is the family ownership of land and forests. This was particularly echoed in Mwanga and Same districts where families/clans own sacred forests that are used for various ritual functions. Conservation of these sacred forests is therefore the responsibility of these families/clans. Similarly, Kihamba belongs to the clan and is distributed according to the number of members in the extended family including the paternal kin [26] [41]-[45]. However, the Kimamba organization has changed substantially with the abolition of chieftaincy and formalization of land management practices. In this study, respondents indicated that they recognize Kihamba as one of the strongest indigenous land management institution that has nevertheless lost its importance due to many reasons including high population growth and the subsequent division of land into small individual units that are mainly used for settlements.

\subsubsection{Traditional Leadership}

Traditional leaders are normally wise men and women who have earned respect due to their involvement in solving existing problems in the society. Reference to these leaders in Kilimanjaro Region is made particularly in relation to the possession of traditional knowledge and the ability to transfer the same across generations. This was a concern of $64.9 \%$ of respondents in the study (Table 5). Comparatively, Siha district indicated the highest level of recognition of the role of traditional leaders followed by Same and Mwanga districts, as reported by $20.6 \%, 16.7 \%$ and $11.1 \%$ of respondents, respectively. Traditional leaders are also currently useful due to their integration in the village government through Village Land Councils, which deal particularly with land-use conflict resolution and awareness raising about tree planting for soil conservation and border demarcation. Although village land councils are not run in traditional ways per se, traditional leaders share their experiences while the rest rely on trainings that are offered by the government and civil society organizations. Focus group discussions revealed that land councils do not have the kind of "powers of knowledge and command" that previous traditional systems of leadership had. However, it is so far the only way that the government has worked with traditional leaders. Strengthening them could therefore work to bridge the gap between conventional and traditional land management systems.

\subsubsection{Mangi Chieftainship}

Chieftaincy was abolished by the government in the 1960s. However, respondents still speak highly of the role of chiefs in keeping order in the society. Although practically Mangi chieftaincy has long been dormant following the government decision, reference to Mangi chieftaincy is made with pride and confidence particularly in relation to its legacy in the protection and management of land and other natural resources. During this study this was reiterated more in Rombo district. Respondents described Mangi chieftaincy to have been a well-organized structure of council members and messengers (commonly known in Kiswahili as wajumbe and matarishi respectively). At different levels, these members and messengers ensured that traditional laws were enforced and order maintained. As indicated Table 5 about $49.6 \%$ of respondents could still recall how this institution operated. Understanding how indigenous institutions lost power of managing resources is an important starting point for the search of ways to harmonize indigenous institutions and modern policies and laws that govern land and other natural resources in the country.

\subsubsection{Social and Resource User Groups}

Villagers are organized in various social groups most of which are for women and youths who participate in 
different activities related to protection of water catchments, tree planting as well as traditional dances. Women groups are particularly more numerous in number. The most common social and resource user groups evident in Kilimanjaro Region are the traditional dances and the irrigation water institution. Traditional dances (e.g. "Mbasa" in Machame) have their roles in knowledge transfer. Although there were no specific dances for particular resources, the message about traditional values and their importance was reported to be carried through songs and sharing of drinks and meat. These dances no longer exist but they are still recalled by elderly respondents as reported by $27.9 \%$ of respondents (Table 5).

The Irrigation water institution (the Mfongo institution), is a very unique and strong water management traditional institution. This institution is still existing but far smaller in scale than it used to be in the past. The institution has also remained with old people who cannot maintain it because the young generation has not shown much interest to take it over. In Rau ward, for example, the Mfongo institution died when its leaders who lived in Kisarika village died. Traditional knowledge on irrigation furrow management included predictions of the amount and timing of rains which helped in the management of these traditional furrows. The leaders (known locally as Wamekuwa Mfungo) had accumulated knowledge that helped in interpreting the position of the moon. Certain positions of the moon were traditionally used to indicate the amount of rainfalls hence preparations for the furrows were done accordingly. Recently, the modernization of traditional furrows involved concretization of irrigation channels hence changing their management from mainly traditional leaders to mainly the village government. The changes have had mixed impacts. Whereas water is better managed in the modern furrows, there have been increased conflicts due to the overlap of responsibilities between traditional leaders and village government that finance the maintenance of the modern furrows. Also local political elites have intervened by, for instance, funding the modernization of the furrows with attached political interests. As the case of Rau suggest, modern interventions have in some cases been very unsustainable due to the lack of ownership by water users and funds for renovations.

\subsubsection{Shared Characteristics of Resource Management Institutions}

Survey results suggest that although there are some differences in what the existing local institutions focus on, most of them (whether indigenous or modern) share one main characteristic; the responsibility of protecting and managing natural resources. Table 6 captures activities of different indigenous and modern institutions. There are those that focus on land and forest protection, water source protection, irrigation water management, tree planting, food crop production, and special ritual performances, among others. However, these institutions differ in their conception, management structures, rules and methods of law enforcement. Success of these institutions is therefore dependent on whether they are formal (where legal actions can be taken) or informal (with informal rules and regulations). On the latter, which is the focus of this study, means of rule enforcement depend on beliefs and specific traditional knowledge which creates taboos and fear of disgrace among community members.

As other data suggests, Same and Mwanga demonstrate that there are many local institutions that deal with land and forest protection. Local narrative indicated that traditional means of rule enforcement have had superior results in protection of these resources. This is confirmed by local perceptions of the existence of some tree species whose ownership by the chief family helped to protect such species for generations (see Table 3).

Respondents suggested also that there is a clear distinction between modern and indigenous institutions although there is currently a trend towards blending core values of the two. When villagers were asked to describe indigenous institutions, the following characteristics were distinct (Table 7). A comparison was also made regarding corresponding modern resource management institutions. The reported blending of these institutions seem to be an important entry point towards integration of indigenous and modern institutions for enhanced sustainability of resource management.

\subsection{Relevance and Effectiveness of Local Knowledge in Addressing Land Degradation}

\section{Usefulness and Effectiveness of Local Knowledge in Addressing Land Degradation}

An inquiry was made on the usefulness and effectiveness of various traditional practices in addressing land degradation. Findings have indicated that a large proportion of respondents implemented traditional practices with aim of preventing soil erosion and improving soil fertility, as indicated by $42.4 \%$ and $26.4 \%$ of respondents respectively (Table 8). Other reported usefulness of the mentioned traditional practices in sustainable land management included soil moisture conservation (7.7\%), soil conservation (6.1\%) and improvement of crop 
Table 6. Percentage response on activities undertaken by the indigenous institution.

\begin{tabular}{|c|c|c|c|c|c|c|c|c|}
\hline Activities & Hai & Moshi MC & Moshi DC & Mwanga & Rombo & Same & Siha & Total \\
\hline Land and forest protection & 10.2 & 15.3 & 3.2 & 39.9 & 14.8 & 79.8 & 37.8 & 28.7 \\
\hline Land protection & 27.5 & 8.6 & 0 & 6.6 & 55.5 & 10.0 & 20.6 & 18.4 \\
\hline $\begin{array}{l}\text { Land and irrigation } \\
\text { furrows (mfungo) }\end{array}$ & 0 & 0 & 3.2 & 0 & 0 & 0 & 13.6 & 2.4 \\
\hline Land and coffee & 0 & 0 & 2.2 & 0 & 0 & 0 & 6.8 & 1.3 \\
\hline Water source protection & 6.8 & 8.8 & 6.4 & 3.3 & 0 & 3.3 & 17.1 & 6.5 \\
\hline Livestock & 0 & 0 & 0 & 6.6 & 0 & 0 & 0 & 0.9 \\
\hline
\end{tabular}

Source: Compiled from Field Work Data, November 2013.

Table 7. Characteristics of resource management institutions as perceived by villagers.

\begin{tabular}{|c|c|c|}
\hline Indigenous institutions & Modern institutions & Mixed institutions \\
\hline $\begin{array}{l}\text { Not legally registered and recognized by the government } \\
\text { hence operate on their own. }\end{array}$ & Known and used by all people. & $\begin{array}{l}\text { Made up of both government and } \\
\text { traditional leaders. }\end{array}$ \\
\hline $\begin{array}{l}\text { Membership based on beliefs and specific traditional } \\
\text { knowledge (e.g. ritual performance). Few people subscribe } \\
\text { to these institutions because not everybody has enough } \\
\text { knowledge of traditions and beliefs associated with them. }\end{array}$ & $\begin{array}{l}\text { Passed through democratic } \\
\text { procedures-discussed and agreed } \\
\text { upon by all members of the village. } \\
\text { Also its leaders are elected based on } \\
\text { their acceptance by the villagers. }\end{array}$ & $\begin{array}{l}\text { Both government laws and } \\
\text { traditions apply. }\end{array}$ \\
\hline $\begin{array}{l}\text { Leadership based on family lineage and inheritance, } \\
\text { loyalty and command of respect. }\end{array}$ & Overseen by the village government. & $\begin{array}{l}\text { Some depend on voluntary } \\
\text { membership (e.g. social groups } \\
\text { and resource user groups). }\end{array}$ \\
\hline $\begin{array}{l}\text { Command of respect based on society's } \\
\text { knowledge of customs and traditions. }\end{array}$ & $\begin{array}{l}\text { Have modern leadership structure- } \\
\text { Chairperson, secretary, treasurer and } \\
\text { members of council. }\end{array}$ & \\
\hline Dependence on informal transfers of knowledge. & $\begin{array}{l}\text { Recognized and report to the ward } \\
\text { and district council. }\end{array}$ & \\
\hline $\begin{array}{l}\text { No cash payments-traditional leaders are paid } \\
\text { through respect from members of the community. }\end{array}$ & $\begin{array}{l}\text { Supported by the government and } \\
\text { other stakeholders (through salaries/ } \\
\text { cash incentives, trainings). }\end{array}$ & \\
\hline $\begin{array}{l}\text { Through the command of respect, the word } \\
\text { of traditional leaders works as a law. }\end{array}$ & $\begin{array}{l}\text { Has legal powers to litigate } \\
\text { hence respected. }\end{array}$ & \\
\hline
\end{tabular}

Source: Compiled from Field Work Data, November 2013.

Table 8. Percentage responses on the effectiveness of the traditional practices by districts.

\begin{tabular}{ccccccccc}
\hline $\begin{array}{c}\text { Effectiveness of the traditional } \\
\text { method/practice }\end{array}$ & Hai & Moshi MC & Moshi DC & Mwanga & Rombo & Same & Siha & Total \\
\hline Preventing soil erosion & 48.3 & 26.1 & 51.5 & 40 & 25.9 & 56.7 & 48.3 & 42.4 \\
Improved soil fertility & 31 & 32.6 & 18.2 & 13.3 & 51.9 & 6.7 & 31 & 26.4 \\
Soil moisture conservation & 6.9 & 4.3 & 18.1 & 10 & 11.1 & 0 & 3.4 & 7.7 \\
Soil conservation & 6.9 & 2.2 & 3.0 & 0 & 3.7 & 26.7 & 0 & 6.1 \\
Improve crop productivity & 3.4 & 10.9 & 0 & 6.7 & 0 & 0 & 6.9 & 4.0 \\
Forest conservation (e.g. & 0 & 0 & 0 & 10 & 3.7 & 0 & 3.4 & 2.4 \\
preventing tree cutting) & 0 & 2.2 & 0 & 10 & 0 & 3.3 & 0 & 2.2 \\
Attract rain & 0 & 0 & 0 & 0 & 0 & 0 & 3.4 & 0.5 \\
Irrigation & 0 & 0 & 0 & 3.3 & 0 & 0 & 0 & 0.5 \\
Marking farm boundaries & 0 & 0 & 0 & 0 & 0 & 0 & 3.4 & 0.5 \\
Wind break & 3.4 & 21.7 & 9.1 & 6.7 & 3.7 & 6.7 & 0 & 7.3 \\
Not applicable & 100 & 100 & 100 & 100 & 100 & 100 & 100 & 100 \\
Total & & & & & & &
\end{tabular}

Source: Compiled from Field Work Data, November 2013. 
productivity (4.0\%).

As shown in Table 8 there are variations in responses between districts. For instance, Same, Moshi Rural, Hai, Siha and Mwanga districts, in that order, were more concerned about the need for preventing soil erosion, which could be attributed to hilly landscape features with more risks of erosion compared to other districts. Information from key informants confirmed that in some of these districts, such as Same and Mwanga they experience gully erosion in various place, hence also confirming the concern by the respondents in this study on the need to address soil erosion. However, Siha has not yet experienced serious erosion. The concern in this district on soil erosion control may perhaps be attributed to higher environmental awareness.

Although other practices were mentioned by much fewer respondents, if well organised and promoted may enhance the sustainability of natural resource management, and minimizing land degradation, for instance through traditional forest conservation practices that, for example, prevent forest tree cutting.

The perceived usefulness of the traditional practices of land management in the area is also demonstrated by the duration of their existence and utilization. Table 9 presents the responses on the length of time that respondent households have been involved in the various traditional land management practices. A larger proportion (64.9\%) of male respondents reported that these practices have, for generations, been practiced and have been effective, followed by $27.3 \%$ who reported to have been involved since childhood. However, as with other practices, there were considerable variations between districts. For instance, in Rombo, Mwanga and Moshi Rural Districts interviewed people indicated to have experienced or practiced such traditional land management practices for generations as reported by $93.8 \%, 83.3 \%$ and $72.2 \%$ of respondents respectively. Some of the respondents have experienced such practices only recently, as reported by $57.9 \%$ and $52.6 \%$ of respondents in Hai and Same districts respectively (Table 9). The variations in responses could be explained by the earlier reported landscape features that have influenced the need for particularly traditional land management practices/methods.

Comparing such experiences by gender, it appears that there are no significant differences between those reporting traditional/indigenous practices to have been practiced for generations or since childhood (Table 9). However, there was a larger proportion of male respondents (18\%) reporting that such practices have been in place only recently, compared to only $5.6 \%$ among female respondents. This may be influenced by the relatively shorter duration of stay in the area among the female respondents. As such, this group of respondents may have lesser experience on traditional/indigenous or sustainable land management practices of the area. This demonstrates that traditional knowledge is acquired through experience to the local environment. Presence of respondents indicating that they are unaware or having limited knowledge of traditional practices of Kilimanjaro Region could be attributed to issues of marriage and migration where some people migrate and/or get married into the region from other places with different traditional practices. The men in this category mainly attributed their lack of such knowledge to migration, as they moved into the region for various reasons such as business and/or employment. However, these findings indicate that for more sustainable resource management, gender concerns have to be considered especially because in many parts of Tanzania and elsewhere in the world women play a crucial role in resource manage. Gender mainstreaming may need recognition and documentation of the good practices and having gender mainstreaming strategy [40].

\subsection{Integration of Indigenous Knowledge in Policy Process and Governance}

\subsubsection{Strengths and/or Weakness of Traditional Institutions in NRM}

The traditional institutions under play in Kilimanjaro Region and there characteristics have been presented in

Table 9. Percentage response on perceived existence and length of use of traditional practice.

\begin{tabular}{cccccccccc}
\hline Sex & Length of time & Hai & Moshi MC & Moshi DC & Mwanga & Rombo & Same & Siha & Total \\
\hline \multirow{2}{*}{ Male } & Existed for generations & 57.9 & 47.1 & 72.2 & 83.3 & 93.8 & 52.6 & 47.4 & 64.9 \\
& Since childhood & 31.6 & 47.1 & 16.7 & 0 & 6.3 & 42.1 & 47.4 & 27.3 \\
& Recently & 19.0 & 17.0 & 18 & 18 & 16.0 & 19.0 & 19.0 & 18.0 \\
\multirow{3}{*}{ Female } & Existed for generations & 40 & 31.0 & 69.2 & 66.7 & 90.9 & 54.5 & 60.0 & 58.9 \\
& Since childhood & 30.0 & 37.9 & 15.4 & 25.0 & 0 & 36.4 & 40 & 26.4 \\
& Recently & 20.0 & 3.4 & 7.7 & 8.3 & 0 & 0 & 0 & 5.6 \\
& Total & 100 & 100 & 100 & 100 & 100 & 100 & 100 & 100 \\
\hline
\end{tabular}

Source: Compiled from Field Work Data, November 2013. 
Section 4.3. Historically, local institutions have ensured that local resources are managed sustainably. This indicates that they have been strong and effective throughout the historical times. This is confirmed by the fact that these institutions have managed to sustain the local resources for generations, as indicated by majority of people in the region. However, as indicated there are people in Kilimanjaro Region that seems to be unaware of the existence of traditional or indigenous institutions for sustainable land management. This raises some questions as to the sustainability of the institutions themselves. It also raises concerns on the future land resource management in the area. Such experience may indicate that the traditional institutions have not adequately promoted themselves to capture the interest, attention and practice of all generations, possibly in favour of more modern and conventional practices as discussed earlier. This may be viewed to be among the weaknesses facing traditional institutions in the region, and possibly elsewhere in the country and globally.

An alternative argument may be that the inadequate recognition of indigenous institutions indicates that national level institutions have become of greater influence at the local level, thereby superseding the indigenous institutions. To ensure that succession of traditional practices related to sustainable land management is achieved across generations, such indigenous and local experiences have to be integrated into the national policies, strategies and plans so that they are as well recognized and enforced at the higher level.

\subsubsection{Potential for Integration of Indigenous Institutions in Formal Policy Processes}

Although the Tanzanian government has not established any specific policy which deals with traditional, local, or indigenous knowledge, considerable attempts have been made to integrate such knowledge systems by including policy issues in various sector policies and strategies. Table $\mathbf{1 0}$ presents examples of the policy statements and issues that have been integrated in selected sector policies, strategies and/or regulations. As can be seen in this table there are several policies and policy issues that support the integration of traditional, local, or indigenous knowledge in respective sector activities, which have relevance to sustainable land management. These may be interpreted to form an important platform for ensuring that local natural resource management institutions are integrated in sector policies and strategies. A few examples are further elaborated in the following below.

National Environmental Policy (1997): The Government promulgated the National Environmental Policy in 1997, which among other things reflects on the outcome of the United Nations Conference on Environment and Development. It recognizes the Rio Declaration and Agenda 21. The policy reiterates that:

"In Agenda 21 the need to move from a development model in which sectors act independent of each other, to a model in which there is integration across sectors, where decisions take into account inter-sectoral effects, to improve inter-sectoral coordination. This involves the integration of policies, plans and programmes of interacting sectors and interest groups to balance long-term and short-term needs in environment and development."

Although the National Environmental Policy contains no specific statements on local, indigenous or traditional knowledge these issues are implied by the fact that there are relevant parts of the National Environmental Policy that indirectly deal with local, indigenous or traditional knowledge, especially those dealing with technology, biodiversity and public participation [47]-[55]. This is one of the reasons why it may be advisable in Tanzania to discuss the issue of local, traditional/indigenous knowledge in tandem with access to resource management issues.

Sustainable Industrial Development Policy 1996-2020: The Government in 1996 formulated the Sustainable Industrial Development Policy, 1996-2020. The Policy does not expressly local, indigenous or traditional knowledge, but is relevant in the discussion of these issues as it deals also with issues of intellectual property rights. The Policy states that:

“Tanzania has adequate intellectual property laws to regulate intellectual property. There are legislations to regulate of acquisition of patent rights in new inventions and innovations, and assurance of effective protection of all such patent rights, as well as to protect the right to use trade and service marks, the right to sue for infringement and pass-offs as well as legislations for copyrights and neighbouring rights. Tanzania being a signatory to the World Trade Organization will abide by the trend of protection within the Trade Related Aspects of Intellectual Property Rights”.

The mention of copyright and neighbouring rights, patents, trademarks and services covers knowledge as well 
Table 10. Examples of the policy statements and issues integrating indigenous knowledge.

\begin{tabular}{cc}
\hline Policy/strategy & Statements/issues relevant to indigenous knowledge \\
\hline $\begin{array}{l}\text { National } \\
\text { Environmental }\end{array}$ & $\begin{array}{c}\text { Reiterates the need for the integration of policies, plans and programmes of interacting sectors and interest } \\
\text { groups to balance long-term and short-term needs in environment and development, including the need to } \\
\text { Policy of } 1997\end{array}$ \\
improve inter-sectoral coordination.
\end{tabular}

Agriculture and Livestock Policy 2013

The National Forest Policy of 1998

National Beekeeping Policy of 1998

Forest Regulations of 2004

The National Wildlife Policy of 1998

Cultural Policy of 1997

National Strategy for Growth and Reduction of Poverty

(MKUKUTA), 2005,

Cluster 1; Growth and Reduction of Income Poverty

National Fisheries Sector Policy and Strategy Framework of 1997
Section 3.1 Research and Development (p. 11) The policy recognized the importance of indigenous/traditional knowledge in relation to agricultural research and it states that: Indigenous knowledge shall be integrated into scientific research; Section 3.5 (Agricultural Extension Services, page 14) states that "The transformation of agricultural extension services is important in order to impart the right tools, knowledge and skills as well as ensuring farmers adhere to good agricultural practices”, which implicitly addresses good indigenous practices. Section 3.26 Gender states that: 1) The Government shall facilitate equal access to land to both men and women;

2) Participation of men and women in decision making processes to improve their access to productive resources shall be enhanced; and 3) Awareness creation and sensitization of communities on negative cultural attitudes and practices shall be promoted in collaboration with the ministry responsible for gender.

The National Forest Policy formulated in 1998 makes extensive reference to biological diversity issues. It mainly deals with flora and it has an express provision on local, indigenous and traditional knowledge in relation to sustainable forest management. The Policy states in Section 2.4 (p. 13) that: "That there have been inadequate consultations to encourage grassroots participation in forestry planning and the potential of indigenous knowledge has not been fully utilized. This is partly due to limited resources for participatory consultations.” Such participatory consultations may in this case integrate local/indigenous institutions relevant to sustainable land management.

The National Beekeeping Policy was issued at the same time with the National Forest Policy in 1998. However, the National Beekeeping Policy has no provisions recognizing the potential of indigenous knowledge in beekeeping management and the use of honey and its products, such as the use of honey in traditional medicine, knowledge that needs to be shared and protected [54].

The provisional Rule 52(23) stated issues relevant to indigenous knowledge on community intellectual property right, that: "The community intellectual property rights of the local communities, including traditional professional groups, particularly traditional practitioners, shall at all times remain inalienable, and shall be further protected under the mechanism established by the relevant law relating to intellectual property rights”.

The Wildlife Policy of Tanzania that was adopted in March 1998 emphasizes among other things the need for ensuring the participation of the people through community based natural resource management arrangements.

Section 3.3.8 recognizing the intrinsic value of rural people, states that "enhancing the use of indigenous knowledge in the conservation and management of natural resources”. page 18 (viii) Section 3.2.1 on wildlife protection "to transfer management of WMA to local community thus taking care of corridors, migratory routes and buffer zones and ensure that local community obtain substantial tangible benefits from wildlife conservation. Has a link with Article 8J on Convention on Biodiversity conservation. Under the part dealing with recognition of intrinsic value of wildlife to the rural people the policy states under Section 3.3.8.9 (viii) the need for: "enhancing the use of indigenous knowledge in the conservation and management of natural resources".

Section 3.5.1 States that: Traditional knowledge, skills and technology which are environmentally friendly shall be identified and their use encouraged. (pp. 9-10)

Cluster strategy Section 2.4.5 (for operational target stated increased Agricultural growth from 5\% in 2003 to $10 \%$ in 2010) (p. 6) states that: "Increase training and awareness creation on safe utilization and storage of agro-chemicals (including agriculture and livestock inputs, e.g. cattle dips), and the use of integrated pest control, eco-agricultural techniques, and use of traditional knowledge.” (p. 6)

Goal 4: cluster strategy item 4.7.1 states that: "Develop programmes for increasing local control and earnings in wildlife management areas, and establish locally managed natural resources funds, taping on local traditional knowledge.” (p. 11)

Goal 6. cluster strategy item 6.2.1 states that: "Develop and promote utilization of indigenous energy resources and diversification of energy sources.” (p. 13)

The National Fisheries Sector Policy and Strategy Statement recognize local/traditional knowledge in the part dealing with improved knowledge of the fisheries resources base. Section 3.3 .2 (p. 9) of the policy shows that the fisheries sector is constrained with scanty information on traditional/local knowledge of fisheries resources

(p. 3). Therefore the policy develops an objective (Section 3.3.2) to enhance knowledge of the fisheries resource base. One of the strategies to achieve this is to "Facilitate and promote acquisition and documentation of traditional fisheries knowledge.” (p. 9). 


\section{Continued}

Stated issues relevant to traditional knowledge, for instance: In Section 4.2 dealing with traditional medicine
and alternative healing systems, the policy recognizes that "The role of traditional and alternative health
care to Tanzanian people is significant. It is estimated that about $60 \%$ of the population use traditional and
alternative care system for their day-to-day health care. Traditional and alternative healing services and
conventional health services are complementary to each other". Policy objective 2.4 .9 "Promote traditional
medicine and alternative healing system and regulate the practice”). On research, Section 3.9.3 states:
"Research in traditional medicines will focus on the identification of traditional remedies, screening of
traditional herbal and medicinal materials and assessing the efficacy and safety of the products". Although
the policy does not specifically mention traditional/indigenous knowledge, it states issues relevant to it,
for instance by having statement supporting working together with the traditional healers,
of 2003
traditional nurses and recognising the importance of both traditional and alternative medicines

Source: Compiled from Field Work Data, November 2013 [47]-[54].

as its protection and application. However, taking into account that traditional intellectual property right systems have been problematic when dealing with local, traditional/indigenous knowledge, innovations and technologies under the Convention on Biological Diversity and trade related aspects of intellectual property rights [55].

The National Science and Technology Policy of Tanzania, 1996: The general objective of the National Science and Technology Policy of 1996 include the need to "Establish appropriate legal framework for the development and transfer of technology including intellectual property rights, monitoring and controlling of the choice and transfer of technology, as well as biosafety". Page 5 of this policy states that: "Thus one primary function of a National Science and Technology Policy is to establish relative priorities of programmes for generating new knowledge and to determine strategies for the application of science and technology for development.” On environment- the major sectoral objectives include preservation of the biological diversity, cultural richness and natural beauty of Tanzania. Like many other policies this National Policy on Science and Technology does not expressly provide for local, traditional or indigenous knowledge, which may contribute immensely to development of science and technology at the local level.

As much as the policies recognize the usefulness and the potential of local, traditional or indigenous knowledge that is not followed up with sufficient strategies and activities to effectively share and protect it. There is a need to review the relevant policies and come out with strategies and action plans on the development and protection of local, traditional or indigenous knowledge. As noted in Section 4.3, some of the respondents in Kilimanjaro Region seem to be unaware of indigenous institutions for sustainable land management. While this raises some questions as to the sustainability of the institutions themselves, it also raises concerns on the future land resource management in the area. Inadequate recognition of indigenous institutions may mean that the national level institutions have become of greater influence at the local level, though they may lack the influence of traditional knowledge and practices such as taboos and local beliefs which were very effectively in the management of natural resources in Kilimanjaro as well as other parts of the country. As such the local experiences have to be integrated into the relevant national policies for enhanced sustainability of resource management.

\section{Conclusions}

Indigenous institutions have been very strong and effective throughout the historical times and they for generations managed to sustain the local resources in the Kilimanjaro Region. However, while it is acknowledged that traditional knowledge and indigenous institutions still exist, they are mainly restricted at the individual level, mainly because indigenous institutions that were instrumental in pursuing traditional knowledge are no longer in place, or not as strong as they used to be in the past. This has caused a decline in the use of traditional practices for sustainable land management. In addition, increasing modernization of agriculture and other land use and resource management systems have continued to weaken the role of the intergenerational experiences regarding traditional practices of land management. This is supported by the increasing number of people in the contemporary times that are not involved and/or are not aware of the existence of these traditional practices of sustainable land management. In particular, such experience may indicate that the traditional institutions have not adequately promoted themselves to capture the interest, attention and practice of all generations, possibly in favour of more modern and conventional practices. Regardless of all these constrains and the low rating of the current use of indigenous practices and institutions, field observation proved that there were methods of land management that were still trusted and specifically useful in land protection from various types of soil erosion, 
landslides as well as loss of fertility. For instance, the use of terraces in hilly areas of Mwanga and Same districts, strip terraces, ridges and growing of grasses and trees across slopes has remained useful practices in Moshi District Council, Siha, Hai and Rombo districts.

Although indigenous institutions have remained something of the past they are locally rated as a superior means of dealing with land and other natural resource management problems, especially in areas with greater land management challenges. Based on the dominance of modern institutions different stakeholders agree that there is a need to mainstream traditional practices into the existing structures and policies. There is currently little documentation of the integration of indigenous institutions in village by-laws but there has been a successful but rudimentary attempt, namely, the village land councils which combine both traditional and government leaders. Although there is little in terms of documented evidences of this unity, respondents suggest that formal and informal institutions can work in ways that complement each other by integrating the systems based on cultural values and beliefs with current modernity. This can be achieved by having in places well established policy frameworks that address traditional/indigenous knowledge and institutions. The presence of various sectoral policy statements in support of indigenous practices provides an eminent stepping stone towards preserving indigenous knowledge but the gap exists because there is no platform for a comprehensive promotion of these practices.

\section{Acknowledgements}

This paper is based on a study commissioned by Kilimanjaro Regional Office and UNDP/GEF. We are grateful to them for funding this study. We are specifically thankful to the Kilimanjaro Regional Administrative Secretary's office and the Sustainable Land Management project office in Moshi for all the logistical support throughout the study. Special appreciations are due to Eng. Alfred I. Shayo, Acting Regional administrative Secretary, Mr. Paulo Shayo, the chairman of the Regional Sustainable Land Management project Technical Team, Dr. Francis Mkanda, the Project Technical Advisor and Mr. Damas Masologo, the Acting National Sustainable Land Management Project Coordinator for facilitating the implementation of this study.

\section{References}

[1] Agrawal, A. (1995) Dismantling the Divide between Indigenous and Scientific Knowledge. Development and Change, 26, 413-439. http://dx.doi.org/10.1111/j.1467-7660.1995.tb00560.x

[2] Briggs, J. and Sharp, J. (2004) Indigenous Knowledge and Development: A Postcolonial Caution. Third World Quarterly, 25, 661-676. http://dx.doi.org/10.1080/01436590410001678915

[3] Fabricius, C., Folke, C., Cundill, G. and Schultz, L. (2007) Powerless Spectators, Coping Actors and Adaptive CoManagers: A Synthesis of the Role of Communities in Ecosystem Management. Ecology and Society, 12, 29. http://www.ecologyandsociety.org/vol12/iss1/art29

[4] Yamia, M., Vogl, C. and Hausera, M. (2009) Comparing the Effectiveness of Informal and Formal Institutions in Sustainable Common Pool Resources Management in Sub-Saharan Africa. Conservation and Society, 7, 153-164. http://dx.doi.org/10.4103/0972-4923.64731

[5] Van Vlaenderen, H. (2000) Local Knowledge: What Is It and Why and How Do We Capture It? National Workshop on Gender, Biodiversity and Local Knowledge Systems Links to Strengthen Agricultural and Rural Development, Morogoro, FAO.

[6] Whyte, P. (2003) On the Role of Traditional Ecological Knowledge as a Collaborative Concept: A Philosophical Study. Ecological Processes, 2, 1-12.

[7] Berkes, F. (2008) Sacred Ecology. Routledge, Manitoba, 7.

[8] Kajembe, G.C., Malimbwi, R.E., Zahabu, E. and Luoga, E.J. (2002) Contribution of Charcoal Extraction to Deforestation: Experience from CHAPOSA. Research Report.

[9] Boonto, S. (1993) Indigenous Knowledge and Sustainable Development. International Institute of Rural Reconstruction Symposium Proceedings, Cavite.

[10] Luoga, E.J. (1994) Indigenous Knowledge and Sustainable Management of Forest Resources in Tanzania. Proceedings of the Workshop on Information for Sustainable Natural Resources of Eastern, Central and Southern Africa, Arusha, 4-9 November 1994, 139-148.

[11] Luoga, E.J., Witkowski, E.T.F. and Balkwill, K. (2000) Differential Utilization and Ethnobotany of Trees in Kitulangalo Forest Reserve and Surrounding Communal Lands of Eastern Tanzania. Economic Botany, 54, 328-343. http://dx.doi.org/10.1007/BF02864785 
[12] Berkes, F. and Folke, C. (1998) Linking Social and Ecological Systems: Management Practices and Social Mechanisms for Building Resilience. Cambridge University Press, Cambridge.

[13] Kweka, D. (2004) The Role of Local Knowledge and Institutions in the Conservation of Forest Resources in the Eastern Usambara. UNESCO-Man and Biosphere, Dar es Salaam.

[14] Mowo, J., Adimassu, Z., Masuki, K., Lyamchai, C., Tanui, J. and Catacutan, D. (2011) The Importance of Local Traditional Institutions in the Management of Natural Resources in the Highlands of Eastern Africa. Working Paper No. 134, World Agroforestry Centre, Nairobi. http://www.dx.doi.org/10.5716/WP11085.PDF

[15] World Bank (1998) Indigenous Knowledge for Development: A Framework for Action. World Bank, Washington DC.

[16] Ashenafi, Z. and Leader-Williams, N. (2005) Indigenous Common Property Resource Management in the Central Highlands of Ethiopia. Human Ecology, 33, 539-563. http://dx.doi.org/10.1007/s10745-005-5159-9

[17] Global Strategic Plan for Biodiversity 2011-2020. http://www.cbd.int/decision/cop/default

[18] Kiwanuka, S. (1970) Colonial Policies and Administration in Africa: The Myths of the Contract. African Historical Studies, 3, 295-315. http://dx.doi.org/10.2307/216218

[19] Schneider, L. (2004) Freedom and Unfreedom in Rural Development: Julius Nyerere, UjamaaVijijini and Villagization. Canadian Journal of African Studies, 38, 344-392. http://dx.doi.org/10.2307/4107304

[20] Kisangani, E. (2009) Development of African Administration: Pre-Colonial Times and Since. Administration and Public Policy, 1, 1-7.

[21] Shivji, I. (2012) Nationalism and Pan-Africanism: Decisive Moments in Nyerere's Intellectual and Political Thought. Review of African Political Economy, 39, 103-116. http://dx.doi.org/10.1080/03056244.2012.662387

[22] Liviga, A. (1992) Local Government in Tanzania: Partner in Development or Administrative Agent of the Central Government? Local Government Studies, 18, 208-225. http://dx.doi.org/10.1080/03003939208433639

[23] Kajembe, G.C., Monela, G.C. and Mvena, Z.S.K. (2003) Making Community-Based Forest Management Work: A Case Study from Duru-Haitemba Village Forest Reserve, Babati, Tanzania. In: Kowero, G., Campbell, B.M. and Sumaila, U.R., Eds., Policies and Governance Structures in Woodlands of Southern Africa, Center for International Forestry Research, Jakarta, 16-27.

[24] Ylhäisi, J. (2004) Indigenous Forests Fragmentation and the Significance of Ethnic Forests for Conservation in the North Pare, the Eastern Arc Mountains, Tanzania. Fennia, 182, 109-132.

[25] Maro, P. (1988) Agricultural Land Management under Population Pressure: The Kilimanjaro Experience, Tanzania. Mountain Research and Development, 8, 273-282. http://dx.doi.org/10.2307/3673548

[26] Ikegami, K. (1994) The Traditional Agrosilvipastoral Complex System in the Kilimanjaro Region, and Its Implications for the Japanese-Assisted Lower Moshi Irrigation Project. African Study Monographs, 15, 189-209.

[27] Grove, A. (1993) Water Use by the Chagga on Kilimanjaro. African Affairs, 92, 431-448.

[28] Gillingham, E. (1999) Gaining Access to Water: Formal and Working Rules of Indigenous Irrigation Management on Mount Kilimanjaro, Tanzania. Natural Resources Journal, 39, 419-441.

[29] Tagseth, M. (2008) Oral History and the Development of Indigenous Irrigation: Methods and Examples from Kilimanjaro, Tanzania. Norwegian Journal of Geography, 62, 9-22.

[30] Adams, W., Brun, C. and Havnevik, K. (2010) Studies of the Waterscape of Kilimanjaro, Tanzania: Water Management in Hill Furrow Irrigation. Journal of Geography, 64, 172-173.

[31] Ylhäisi, J. (2006) Traditionally Protected Forests and Sacred Forests of Zigua and Gweno Ethnic Groups in Tanzania. Doctoral Dissertation, Helsingin Yliopiston Maantieteen Laitoksen Julkaisuja, Helsingin.

[32] Mgumia, H. and Oba, G. (2003) Potential Role of Sacred Groves in Biodiversity Conservation in Tanzania. Environmental Conservation, 30, 259-265. http://dx.doi.org/10.1017/S0376892903000250

[33] Msuya, S. and Kideghesho, J. (2009) The Role of Traditional Management Practices in Enhancing Sustainable Use and Conservation of Medicinal Plants in West Usambara Mountains, Tanzania. Tropical Conservation Science, 2, 88-105.

[34] Munger, S. (1952) African Coffee on Kilimanjaro: A Chagga Kihamba. Economic Geography, 28, 181-185. http://dx.doi.org/10.2307/141027

[35] Tagseth, M. (2006) The "Mfongo" Irrigation Systems on the Slopes of Mt. Kilimanjaro, Tanzania. In: Tvedt, T. and Jakonsson, E., Eds., A History of Water Volume I: Water Control and River Biographies, I.B. Tauris, London, 488-506.

[36] Sheridan, M. (2002) An Irrigation Intake Is Like a Uterus: Culture and Agriculture in Pre-Colonial North Pare, Tanzania. American Anthropologist, 104, 79-92. http://dx.doi.org/10.1525/aa.2002.104.1.79

[37] Baumann, O. (1891) Usambara und seine Nachbargebiete. Dietrich Reimer, Berlin.

[38] United Republic of Tanzania, URT (2013) Population and Housing Census: Population Distribution by Administrative 
Areas. National Bureau of Statistics, Ministry of Finance, Dar es Salaam and Office of Chief Government Statistician, President's Office, Finance, Economy and Development Planning, Zanzibar.

[39] Cochran, W.G. (1977) Sampling Techniques. 3rd Edition, John Wiley \& Sons, New York.

[40] Magigi, W. and Sathiel, A. (2014) Gender Consideration in Sustainable Land Management Project Activities on the Highlands of Kilimanjaro Region: Lessons and Future Outlook. Open Journal of Soil Science, 4, 185-205. http://dx.doi.org/10.4236/ojss.2014.45022

[41] O’kting'ati, A., Maghembe, J.A., Fernandes, E.C.M. and Weaver, G.H. (1985) Plant Species in the Kilimanjaro Agroforestry System. Agroforestry Systems, 2, 177-186. http://dx.doi.org/10.1007/BF00147032

[42] Kangalawe, R.Y.M. (2001) Changing Land-Use Patterns in the Irangi Hills, Central Tanzania: A Study of Soil Degradation and Adaptive Farming Strategies. Ph.D. Dissertation, Department of Physical Geography and Quaternary Geology, Stockholm University, Stockholm.

[43] Kangalawe, R.Y.M. (2014) Nutrient Budget Analysis under Smallholder Farming Systems and Implications on Agricultural Sustainability in Degraded Environments of Semiarid Central Tanzania. Journal of Soil Science and Environmental Management, 6, 44-60. http://dx.doi.org/10.5897/JSSEM13.0390

[44] Kajembe, C., Mwaipopo, S., Mvena, K. and Monela, G. (2002) The Role of Traditional Leadership, Institutions and Ecological Knowledge in Sustainable Management of Miombo Woodlands in Handeni District, Tanzania. Policies, Governance and Harvesting Miombo Woodlands, Harare.

[45] Kajembe, G.C., Mwaipopo, S. and Kijazi, M. (2003) The Role of Traditional Institutions in the Conservation of Forest Resources in East Usambara, Tanzania. International Journal of Sustainable Development and World Ecology, 10, 101-107. http://dx.doi.org/10.1080/13504500309469789

[46] Data Collected from In-Depth Interviews with Elderly Person in Rau Ward. Moshi Municipality, Kilimanjaro Region, Tanzania.

[47] United Republic of Tanzania, URT (2013) Agriculture Policy. Ministry of Agriculture, Food Security and Cooperatives, Dar es Salaam.

[48] United Republic of Tanzania, URT (1997) Cultural Policy: Policy Statement of 1997. Dar es Salaam.

[49] United Republic of Tanzania, URT (1997) National Fisheries Sector Policy and Strategy Framework. Ministry of Natural Resources and Tourism, Dar es Salaam.

[50] United Republic of Tanzania, URT (2003) National Health Policy. Ministry of Health and Social Welfare, Dar es Salaam.

[51] United Republic of Tanzania, URT (1998) The National Forest Policy. Ministry of Natural Resources and Tourism, Dar es Salaam.

[52] United Republic of Tanzania, URT (1998) National Beekeeping Policy. Ministry of Natural Resources and Tourism, Dar es Salaam.

[53] United Republic of Tanzania, URT (2004) Forest Regulations of 2004, the Government Notice (GN) No. 153. Ministry of Natural Resources and Tourism, Dar es Salaam.

[54] United Republic of Tanzania, URT (2005) National Strategy for Growth and Reduction of Poverty (MKUKUTA). Government Printer, Dar es Salaam.

[55] Kabudi, P.J. (2003) Benefits and Risks of Sharing Local and Indigenous Knowledge in Tanzania: The Legal Aspects and Challenges. Report No. 5, Links Project: Gender, Biodiversity and Local Knowledge Systems for Food Security, FAO, Rome. 
Scientific Research Publishing (SCIRP) is one of the largest Open Access journal publishers. It is currently publishing more than 200 open access, online, peer-reviewed journals covering a wide range of academic disciplines. SCIRP serves the worldwide academic communities and contributes to the progress and application of science with its publication.

Other selected journals from SCIRP are listed as below. Submit your manuscript to us via either submit@scirp.org or Online Submission Portal.
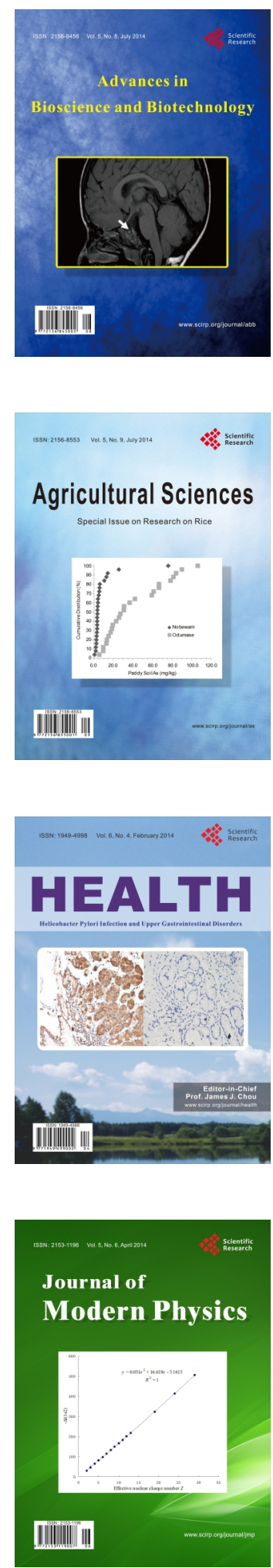
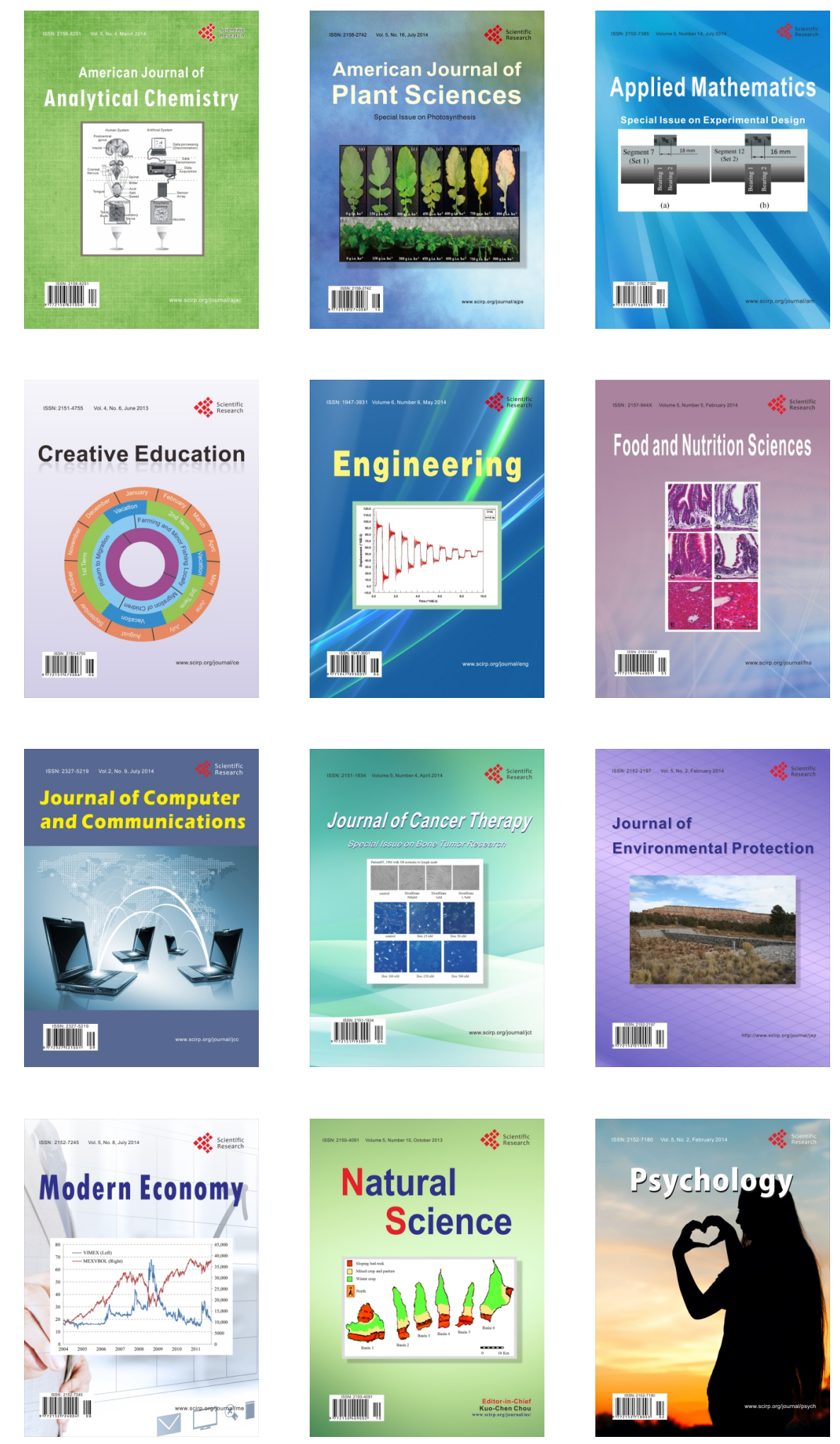